\title{
CENTRO DE CONVIVÊNCIA E RESIDÊNCIA PARA A TERCEIRA IDADE: A ARQUITETURA GUIANDO UM NOVO OLHAR SOBRE A AUTONOMIA E A SOCIALIZAÇÃO DO IDOSO
}

\section{ARTIGO ORIGINAL}

CRUZ, Alice Gabriela Cerqueira ${ }^{1}$, CAVALCANTE, Marília Moreira ${ }^{2}$

CRUZ, Alice Gabriela Cerqueira. CAVALCANTE, Marília Moreira. Centro de convivência e residência para a terceira idade: a arquitetura guiando um novo olhar sobre a autonomia e a socialização do idoso. Revista Científica Multidisciplinar Núcleo do Conhecimento. Ano. 07, Ed. 02, Vol. 05, pp. 05-46. Fevereiro de 2022. ISSN: 2448-0959, Link de acesso: https://www.nucleodoconhecimento.com.br/arquitetura/centro-de-

\section{convivencia}

\section{RESUMO}

O aumento da expectativa de vida e o crescimento da população idosa tem alterado o perfil das demandas por políticas sociais e reforçado a necessidade de ações destinadas a esse público. Nesse sentido, este artigo apresenta um projeto arquitetônico de um Centro de Convivência e Residência para a terceira idade. Visa ter um olhar abrangente sobre as questões do envelhecimento e prestar cuidados integrados, atendendo às complexidades inerentes à idade e às transformações da sociedade. $\mathrm{O}$ artigo busca responder ao questionamento: como a arquitetura de um Centro de Convivência e Residência para a terceira idade pode contribuir para

\footnotetext{
${ }_{1}^{1}$ pós-graduada em gestão de obras na construção civil, pós-graduada em orçamento, planejamento e controle na construção civil, graduada em arquitetura e urbanismo e graduanda em engenharia civil. ORCID: 0000-0002-0629-0753
}

2 Orientador. ORCID: 0000-0001-6852-1417

RC: 107028

Disponível em: https://www.nucleodoconhecimento.com.br/arquitetura/centro-deconvivencia 
aumentar a autonomia dessa crescente população? Nesse sentido, o objetivo geral é projetar um espaço que fomente a autonomia e socialização do idoso. A metodologia se deu através de pesquisas, visitas técnicas, questionário, levantamento e análises de dados nas variadas áreas do conhecimento. O principal resultado foi a produção do projeto arquitetônico de uma instituição de longa permanência para idosos em vulnerabilidade e um centro de convivência intergeracional. Por meio de estratégias de conforto e promoção de acessibilidade e assistência à saúde, as exigências e limitações que o envelhecimento produz foram superadas e foi promovida a autonomia do idoso, propiciando-Ihe liberdade para exercer suas atividades diárias e fomentando a sua socialização.

Palavras-chave: Idoso, envelhecimento; socialização, autonomia, arquitetura.

\section{INTRODUÇÃO}

Este artigo apresenta o projeto de um Centro de Convivência e Residência para a terceira idade, propondo-se ser uma instituição de caráter público, referência em assistência ao idoso. Nesse sentido, além de ser uma instituição asilar, voltada especialmente aos idosos sem famílias, que estão em situação de vulnerabilidade, é também um local para o idoso passar o dia, usufruindo dos serviços de saúde e demais instalações ofertadas. Desse modo, propõe a elaboração de um plano integrado de cuidados, visando o retardamento da perda de autonomia desse idoso e seu possível ingresso em uma Instituição de Longa Permanência de Idosos (ILPI). Visa, assim, promover uma integração intergeracional, buscando a participação das famílias e da comunidade local na atenção aos idosos, seu envelhecimento, sem isolamento social, e com a possibilidade de aumento da renda própria.

Sobre esse tema, segundo o Relatório Mundial de Envelhecimento e Saúde, da Organização Mundial da Saúde (OMS, 2015), o mundo está passando por um acelerado crescimento da população idosa e aumento da longevidade. O relatório ainda afirma que a saúde é essencial para que a pessoa idosa possa desfrutar dos 
benefícios que advêm do aumento da longevidade e que sua autonomia também contribui para isso, sendo, portanto, fundamental para seu bem-estar.

Assim, surge o questionamento: como a arquitetura de um Centro de Convivência e Residência para a terceira idade pode contribuir para aumentar a autonomia dessa crescente população?

Como justificativa para este projeto, afirmamos que, no Brasil, os direitos dos idosos estão assegurados pelo Estatuto do Idoso, a Lei no 10.741 (BRASIL, 2003). O Art. $2^{\circ}$ desse Estatuto declara que, além dos direitos fundamentais inerentes à pessoa humana, ao idoso são asseguradas "todas as oportunidades e facilidades para preservação de sua saúde física e mental e seu aperfeiçoamento moral, intelectual, espiritual e social, em condições de liberdade e dignidade" (BRASIL, 2003). No entanto, segundo aponta o anexo da Portaria ํㅡㄹ.528, de 19 de outubro de 2006, do Ministério da Saúde (BRASIL, 2006), a cobertura dos serviços públicos de saúde e a quantidade de instituições públicas de longa permanência para a população da terceira idade são insuficientes para atender à demanda existente.

A mudança na distribuição etária da sociedade, através do aumento da expectativa de vida e do crescimento da população idosa, tem alterado o perfil das demandas por políticas sociais e reforçado a necessidade de ações destinadas a esse público (BATISTA et al., 2008). Assim, segundo a Organização Mundial da Saúde (OMS) é necessária e urgente uma ação de saúde pública abrangente, com a "transformação dos sistemas de saúde, longe dos modelos curativos baseados em doença e para a prestação de cuidados integral e centrados em adultos maiores" (OMS, 2015, p. 25).

Desse modo, é benéfica e necessária a implantação de um centro com profissionais capacitados e equipado com uma estrutura física que fomente a autonomia do idoso, retardando ou excluindo a sua ida a uma instituição de longa permanência e maiores cuidados familiares. Por isso, este projeto visa ser um espaço arquitetônico de qualidade para atender o idoso, pensando sempre na manutenção de sua saúde física e mental.

RC: 107028

Disponível em: https://www.nucleodoconhecimento.com.br/arquitetura/centro-deconvivencia 
Nesse sentido, o objetivo geral deste projeto é arquitetar um espaço que fomente a autonomia e socialização do idoso. Além disso, visa promover a saúde, cultura e lazer da pessoa idosa, projetar espaços que atendam às suas demandas sociais, sanitárias, econômicas e afetivas, além de promover integração desses idosos a partir das atividades desenvolvidas no Centro, com a comunidade local, e incentivar relações intergeracionais.

Dando viabilidade ao projeto, no âmbito urbanístico e paisagístico, o terreno escolhido localiza-se na Av. Luiz Tarquínio, 20, Boa viagem, Salvador - BA, CEP 40414-120. O local foi escolhido por ser esse um bairro com um dos maiores índices de população idosa em Salvador, 15,93\% da população do bairro, segundo dados do Censo do Instituto Brasileiro de Geografia e Estatística (IBGE) de 2010 (BRASIL, 2010). Aliado a esse fator, verifica-se uma renda média dos responsáveis pelos domicílios bem abaixo dos bairros na liderança do percentual de idosos, como Canela, Graça e Vitória, que têm entre $20 \%$ e $18 \%$ de sua população idosa, chegando a uma renda quatro vezes menor, ponto importante a se considerar para atender a essa população menos favorecida.

O bairro da Boa Viagem, onde está localizado o terreno, é carente de espaços públicos e, em contrapartida, apresenta diversos vazios urbanos, resultantes do fechamento das fábricas situadas na região, como o terreno em questão, que abrigava um antigo galpão de uma fábrica.

Ademais, esse terreno tem um grande potencial paisagístico, banhado pela Baia de Todos os Santos, com acesso à praia, o que será extremamente benéfico para o bemestar dos idosos. Atualmente, esses potenciais estão perdidos, com 0 uso incompatível ao valor histórico e arquitetônico do edifício nele instalado, sendo utilizado como um terminal destinado à guarda de mercadorias alfandegadas, chamado de Estação Aduaneira Interior (EADI), pertencente à Companhia Empório de Armazéns Gerais Alfandegados. Além disso, não atinge o coeficiente de aproveitamento mínimo do terreno, descumprindo, então, a função social da 
propriedade prevista na Constituição de 1988. Assim, a desapropriação do terreno é justificada pela intenção de uso de caráter público, desapropriação disciplinada pelo Decreto-Lei 3.365/1941 (BRASIL, 1941), que caracteriza a desapropriação por utilidade ou necessidade pública, explorando melhor a função social da propriedade e dispondo de maiores benefícios à sociedade com a implantação deste Centro.

A metodologia usada para a estruturação deste projeto se deu através de diversas atividades com o objetivo de compreender melhor o objeto proposto e elaboração do projeto. Assim, as etapas da pesquisa foram:

- Levantamento de dados: investigação realizada nas diversas áreas do conhecimento (saúde, psicologia, política, história e arquitetura); foi necessário também um prolongado estudo sobre o envelhecimento e as transformações da sociedade; também uma análise dos índices do IBGE para dados estatísticos e orientações da OMS para a saúde do idoso, assim como o Estatuto do Idoso (BRASIL, 2003);

- Visitas técnicas: realização de visitas técnicas ao terreno escolhido e a instituições de longa permanência de idosos;

- Entrevistas e questionários: realizadas com idosos;

- Análises dos dados obtidos e produção da parte escrita da monografia;

- Seleção de projetos de referência;

- Estudo do terreno e seu entorno: histórico da área, condicionantes físicos, ambientais e legais;

- Estudo das normas técnicas aplicadas à temática, como a NBR 9050 (ASSOCIAÇÃO BRASILEIRA DE NORMAS TÉCNICAS, 2020), a Portaria oㅡ 73 da Secretaria de Políticas de Assistência Social (BRASIL, 2001), a RDC 283 (BRASIL, 2005) da Agência Nacional de Vigilância Sanitária, dentre outras normas técnicas;

- Estudo de demandas;

- Produção do programa de necessidades e pré-dimensionamento; 
- Desenvolvimento do anteprojeto arquitetônico: com a produção de todas as peças gráficas: planta de localização, planta de situação, plantas-baixas, plantas de layout com cortes, fachadas, detalhamentos; planta estrutural; memorial descritivo e perspectivas.

\section{EMBASAMENTO TEÓRICO}

\subsection{O ENVELHECIMENTO}

Segundo a Organização das Nações Unidas (2015), o mundo está passando por uma transição no seu processo demográfico: à medida que taxas de fertilidade vem diminuindo, o percentual de pessoas com 60 anos ou mais deve duplicar entre 2007 e 2050. Atualmente, o crescimento da população idosa acontece a uma taxa de $3 \%$ por ano e, pela primeira vez na história, há mais idosos no mundo que crianças (ORGANIZAÇÃO DAS NAÇÕES UNIDAS, 2019).

Dados do Instituto Brasileiro de Geografia e Estatística (BRASIL, 2010) mostram que no Brasil, entre 2000 e 2010, a população de idosos cresceu 41\%. Esse órgão afirma que o país deve demorar 50 anos para quadruplicar, de $7 \%$ para $28 \%$, seu contingente de pessoas com mais de 65 anos. Segundo a OMS (2005), a França teve, aproximadamente, 115 anos para adaptar seus sistemas políticos e sociais a uma mudança de $7 \%$ para $14 \%$ da população com mais de 60 anos, enquanto países, como o Brasil, a China e Índia terão pouco mais de 20 anos para fazer a mesma adaptação.

Ademais, de acordo com o IBGE (BRASIL, 2010), a expectativa de vida do brasileiro no ano 2000 era de 68,6 anos. Em 2010, essa expectativa era de 73,9 anos, já para o ano 2040, a previsão é de 79,9 anos e, para 2060, de 81,2 anos.

Além disso, ainda segundo o IBGE (BRASIL, 2017), no Brasil, entre 2012 e 2017, o número de pessoas nos asilos públicos cresceu $33 \%$, passando de um total de 45,8 
mil para 60,8 mil. Levando em consideração também as instituições privadas, esse número chega a 100 mil idosos em instituições de longa permanência.

Para a realidade do projeto, no estado da Bahia, segundo aponta a Pesquisa Nacional por Amostra de Domicílios Contínua (PNAD Contínua) do IBGE, realizada entre 2015 e 2016 (BRASIL, 2016), a quantidade de idosos na Bahia chega a dois milhões e o estado é o sétimo no país em aumento da população idosa.

Em Salvador, o cenário não é outro. A Pesquisa do PNAD Contínua (BRASIL, 2017) mostra ainda que Salvador tem a maior expectativa de vida entre as capitais do Nordeste e que, com $15,1 \%$ de idosos, a cidade chegou ao 9 o lugar no ranking das capitais mais envelhecidas do Brasil, superando Curitiba, Goiânia, Campo Grande e Cuiabá.

No entanto, há o problema do desamparo familiar e da violência contra idosos. No período de 2009 a 2015, segundo dados da Secretaria Municipal da Saúde de Salvador (2018), foram notificados 679 casos de violência contra idosos. A secretaria ainda se preocupou em ressaltar o "desafio de notificar tais casos, dado a tendência de ser naturalizado pela organização domiciliar, envolvendo aspectos como imperativos familiares, normas culturais e inúmeras situações que mascaram a ocorrência do agravo" (SALVADOR, 2018).

$\mathrm{Na}$ esfera pública, as adversidades são grandes. Apesar de um envelhecimento saudável em condições de dignidade ser um direito da população idosa e o Estado ter a obrigação de garanti-lo, através do Art. 9ํำ do Estatuto do Idoso (BRASIL, 2003), não há uma quantidade suficiente de projetos para reforçar os cuidados assistenciais e prolongados à velhice, além de faltarem espaços de uso público e assistência à saúde (BRASIL, 2006).

É certo que a longevidade e o constante aumento da população idosa são conquistas da humanidade, resultado do progresso tecnológico e econômico da sociedade. Mas, como é possível perceber esse crescimento também gera sérias consequências, 
exigindo uma resposta rápida e adequada a essas mudanças. Além da necessidade de aprimoramento profissional nas áreas de saúde, de se planejar melhor a previdência e de se repensar os espaços projetados para essa população, é preciso também mudar as visões largamente reforçadas acerca do envelhecimento.

Ao envelhecimento estão relacionados diversos fatores biológicos, ambientais e psicológicos (OMS, 2005). O fator biológico, por exemplo, é caracterizado pela deterioração funcional gradativa da pessoa, resultando em perda de resposta rápida a situações e aumento do risco a diversas doenças. Já o fator psicológico, é caracterizado pelo declínio das funções cognitivas. Isso gera um estereótipo de discriminação etária generalizado de que as pessoas mais velhas são dependentes, ou de que elas são um fardo. Essas atitudes negativas têm consequências significativas sobre a saúde mental e física dos idosos, correndo o risco de sofrerem depressão e isolamento. Nesse sentido, um estudo da Organização Mundial da Saúde (OMS), realizado em 57 países no ano de 2016, constatou que pessoas com um estado de ânimo negativo em relação ao seu próprio envelhecimento vivem em média 7,5 anos a menos que outras que apresentam um estado de ânimo positivo (RIO DE JANEIRO, 2016).

Mas, por outro lado, conforme também declara a OMS (2015), os idosos ainda contribuem socialmente, por meio de impostos, gastos próprios de consumidores e outras atividades de valor econômico, ou formas menos tangíveis economicamente, por exemplo, fornecendo apoio emocional à família. Além disso, demonstram grandes potenciais para o mercado de trabalho, como experiência, paciência e muita vontade de aprender.

Assim, os gastos em sistemas de saúde, cuidados de longo prazo e ambientes mais amplos e propícios devem ser vistos como investimentos e não como custos, já que eles permitem maior participação, desenvolvimento de capacidades e o bem-estar dos idosos. De acordo com a Organização Mundial da Saúde (2005), mudanças no ambiente podem diminuir o limiar da deficiência e, assim, reduzir o número de pessoas 
com incapacidade em uma comunidade. Além disso, sabe-se que um estilo de vida saudável pode reduzir e retardar os efeitos do envelhecimento. Ainda segundo a OMS (2005), os processos capacitadores recuperam a função e aumentam a participação dos idosos em todas as atividades da sociedade. Entre eles é possível destacar,

Programas de exercícios que ajudam as pessoas idosas a manter sua mobilidade ou a recuperar a força nas pernas que precisam para se locomover [...], programas permanentes de aprendizagem e alfabetização [...], aparelhos auditivos ou ensino da linguagem de sinais que capacitam os idosos com problemas de audição para continuar se comunicando com os outros [...], livre acesso a postos de saúde, programas de reabilitação [...]. (ORGANIZAÇÃO MUNDIAL DA SAÚDE, 2005, p. 37).

Assim, auxiliando esse desenvolvimento, "a mudança de atitude dos provedores de serviço social e de saúde é primordial para assegurar que suas práticas capacitem os indivíduos a permanecerem autônomos e independentes pelo período mais longo possível" (OMS, 2005). Dessa forma, o enfoque social deve relacionar-se a modelos de prevenção e não modelos curativos baseados na doença. Além disso, deve-se estimular ações de conscientização como previsto pelo Estatuto do Idoso (BRASIL, 2003), no Art. 22, através da necessidade de respeito e valorização do idoso, de forma a eliminar o preconceito e a produzir conhecimentos sobre a matéria. Para isso, é necessária a inclusão desse idoso, estimulando seu convívio com pessoas de outras gerações, a fim de reduzir esse preconceito etário através da troca de experiências e conhecimentos.

\subsection{BREVE HISTÓRICO SOBRE O TEMA}

Por conta das questões relatadas acima, surgiram, ao longo das últimas décadas, diversos modelos de atendimento ao idoso, divididos na modalidade asilar e nãoasilar, sendo categoria à parte aquelas iniciativas da própria comunidade. Abaixo, estão as principais definições das formas de atendimento e serviço aos idosos, segundo a Portaria MPAS/SEAS nำ3 (BRASIL, 2001), 
- Atendimento integral institucional: é aquele prestado prioritariamente aos idosos em situação de vulnerabilidade, em regime de internato, sem duração de estadia determinada, podendo ser uma instituição pública ou privada. Dispõe de quadro de funcionários para atender às necessidades básicas dos usuários e realizar práticas que melhorem a qualidade de vida. Ainda segundo a Portaria no 73, são exemplos de denominações a esse tipo de atendimento: ancianato, abrigo, casa de repouso, clínica geriátrica e asilo.

- Residência Temporária: destinado à internação temporária por, no máximo, 60 dias, do idoso dependente, que necessite de cuidados biopsicossociais sistematizados.

- República: voltado aos idosos independentes, podendo ser organizada em sistema de autogestão e custeada com recursos de sua

- Centro de convivência: local que possibilita a convivência de idosos e familiares, objetivando aumentar a qualidade de vida e a integração intergeracional.

- Centro-dia: destinada a idosos dependentes que moram com suas famílias, mas que não possuem assistência em tempo integral em suas residências. Pode funcionar como um Centro de Convivência contanto que tenha funcionários capacitados a auxiliar os idosos em suas necessidades básicas e que realizem atividades terapêuticas, sociais e culturais.

- Casa Lar: voltada a idosos sem renda suficiente para sobrevivência. Tem uma proposta participativa, de modo a aumentar a autonomia dos idosos e desestimular práticas tutelares e assistencialistas. Estimula o contato com a vizinhança e a rede de serviços da proximidade.

Neste trabalho, o modelo proposto é uma combinação das noções de Atendimento integral institucional, Centro de convivência, Centro-dia e Casa Lar.

Em um breve histórico, no mundo, conforme Araújo; Souza e Faro (2004), a primeira instituição de Longa Permanência foi fundada pelo Papa Pelágio II (520-590) que transformou sua casa em um hospital para idosos. Já no Brasil, a noção de asilo 
remonta a 1794 quando, no Rio de Janeiro, o Conde de Resende fundou a Casa dos Inválidos, "como reconhecimento àqueles que prestaram serviço à pátria, para que tivessem uma velhice tranquila" (ARAÚJJ; SOUZA; FARO, 2004). No entanto, de fato, a primeira instituição para idosos foi o Asilo São Luiz para a Velhice Desamparada, também no Rio de Janeiro, criada em 1890 para idosos em situação de pobreza e exclusão social. Mas, de acordo com Araújo; Souza e Faro (2004), ao ingressar na instituição, os idosos deveriam romper as relações com a família e a sociedade.

Em relação aos Centros de Convivência para a Terceira Idade, segundo Hallack (2018), estes surgiram no país inspirados em modelos franceses e estadunidenses, através da iniciativa do Departamento Regional do Serviço Social do Comércio (SESC) de São Paulo, a partir de 1963. Em 1975, os centros de convivência foram incluídos em iniciativas estatais por meio da criação do Programa Nacional de Assistência ao Idoso pelo Instituto Nacional de Previdência Social (INPS) (HALLACK, 2018).

\section{DIAGNÓSTICO DA ÁREA DA PESQUISA E PRÉ-EXISTÊNCIA}

Aqui serão expostos os fatores que configuram a área da pesquisa e a edificação existente no local, que demonstra notória importância histórica, cultural e arquitetônica.

\subsection{BREVE HISTÓRICO DA ÁREA E EDIFICAÇÃO}

O bairro em questão está localizado na península de Itapagipe, vizinha à Baía de Todos os Santos. De acordo com o livro O caminho das águas em Salvador (SANTOS et al., 2010), no final do século XIX, houve um período de ocupação acentuada nessa região com a instalação de várias indústrias, principalmente, as de tecido de algodão. Até a metade do século XX, essa foi a região de Salvador que abrigou o maior número de indústrias. Ainda segundo os autores, atualmente, a Península de Itapagipe apresenta muitas marcas de uma ocupação desordenada e de infraestrutura precária. 
O bairro de Boa Viagem tem sua origem no entorno da Igreja de Nossa Senhora da Boa Viagem, fundada entre 1712 e 1714 (SANTOS et al., 2010). Sua via principal é a Avenida Luiz Tarquínio, logradouro onde será localizado este projeto. O nome da via homenageia o industrial Luiz Tarquínio, pioneiro das indústrias têxteis do Brasil. Ele construiu a primeira vila operária de Salvador, a vila operária da Boa Viagem, em 1892, inspirado nos condomínios operários britânicos. Seu objetivo era abrigar os funcionários da Empório Industrial do Norte, companhia localizada no terreno deste projeto, que teve sua construção iniciada em 1891, fundada em conjunto com os comerciantes Leopoldo José da Silva e Miguel Francisco Rodrigues de Moraes (SAMPAIO, 1975 apud LUTHER, 2019).

Também conhecida como Fábrica da Boa Viagem ou Fábrica de Luiz Tarquínio, a Companhia Empório Industrial do Norte iniciou suas atividades em 1893, contando com várias ampliações ao longo do tempo. Tornou-se a maior indústria têxtil da Bahia, com o maior número de teares (899), operários (697) e maior produção, alcançando, em pouco tempo, a posição de maior do Norte e Nordeste e uma das maiores do país (LUTHER, 2019).

A Vila Operária da Companhia Empório Industrial do Norte "contava com praça arborizada, dois coretos, farmácia, armazém, biblioteca e os filhos dos funcionários tinham acesso à educação, além dos cursos noturnos para adultos; creche, assistência médica e dentária" (SANTOS et al., 2010). Assim como a fábrica, a vila também teve um crescimento acelerado. Segundo Luther (2019), três anos após sua inauguração em 1892, no ano de 1895, contava com 162 casas e 800 habitantes; já no ano de 1898, chegava a 258 unidades e 1500 moradores. Hoje, os traçados originais das casas já foram modificados pelos sucessivos moradores, desde a estrutura interna, até as fachadas dos prédios.

Segundo a Fundação Gregório de Mattos (SALVADOR, 2020), a intenção de Luiz Tarquínio era fazer dessa vila a melhor vila operária do país. Opondo-se ao 
pensamento escravagista da época, Luiz Tarquínio defendia que o trabalho produtivo dependia de boas condições de vida para os funcionários.

Apesar das crises ocorridas durante a primeira metade do século XX, com as guerras mundiais e a Grande Depressão de 1929, a fábrica manteve-se estável. Segundo Luther (2019), foi apenas em 1963 que a Companhia entrou em decadência, não obtendo mais lucros a partir de 1965. Em 1973, foi então vendida ao grupo Atlântico Sul - Comércio Exportação e Importação S.A. Atualmente, é uma Estação Aduaneira Interior, pertencente à Companhia Empório de Armazéns Gerais Alfandegados, que realiza armazenamento de contêineres, com grande circulação de caminhões.

Ainda conforme a Fundação Gregório de Mattos (SALVADOR, 2020), depois da falência da fábrica na década de oitenta, as escrituras das casas foram repassadas pelo Governo do Estado aos antigos moradores, ex-operários, e seus descendentes.

\subsection{JUSTIFICATIVA DA PRESERVAÇÃO}

Segundo o Decreto Lei no 25 (BRASIL, 1937), que trata do Patrimônio Histórico e Artístico Nacional, em seu Art. 1을

Constitui o patrimônio histórico e artístico nacional o conjunto dos bens móveis e imóveis existentes no país e cuja conservação seja de interesse público, quer por sua vinculação a fatos memoráveis da história do Brasil, quer por seu excepcional valor arqueológico ou etnográfico, bibliográfico ou artístico. (BRASIL, 1937, Art. 1ำ).

É fato que a construção em análise não está inserida em um dos quatro Livros do Tombo, mas é inegável que sua conservação é relevante, segundo os critérios citados, uma vez que conta a história do bairro da Boa Viagem, com um enorme valor histórico para o local, sendo a Companhia Empório Industrial do Norte ponto de partida para a criação da vila operária que povoou o bairro da Boa Viagem. Um exemplo de sua importância é que, segundo moradores do local, o tombamento da vila e da fachada da fábrica foi pedido junto ao IPHAN desde 2009, sem, no entanto, haver progresso nesse sentido.

RC: 107028

Disponível em: https://www.nucleodoconhecimento.com.br/arquitetura/centro-deconvivencia 
Segundo Luther (2019), o conjunto da Companhia Empório Industrial do Norte é o patrimônio industrial de maior destaque na Península de Itapagipe. Nesse sentido, a construção está intimamente ligada à identidade do local, o que auxilia na construção da sensação de pertencimento e cidadania. Assim, sua preservação é imperativa, mesmo que não parta do poder público, demarcando esta característica única da região e responsabilizando-se pela transmissão do legado histórico às próximas gerações, no sentido de integrá-lo à vida contemporânea através do novo uso proposto. Essa ação se justifica uma vez que o atual uso não promove a integração esperada, pois desconsidera sua história, arquitetura e os potenciais do terreno. Nesse sentido, levando em conta os aspectos mencionados anteriormente, a finalidade desta restauração deve ser a salvaguarda da obra e do seu testemunho cultural. Assim, seguindo os preceitos da Carta de Veneza (CONSELHO INTERNACIONAL DE MONUMENTOS E SÍTIOS, 1964), para viabilizar a conservação desse patrimônio, deve-se atribuir-Ihe utilização e função social, sem que, no entanto, descaracterize a simbologia histórica.

Segundo o projeto, será implantado um pequeno museu no setor de convivência desse Centro que reunirá documentos, fotos e demais peças que contam a história da Companhia Empório Industrial do Norte e da evolução das indústrias na Península de Itapagipe. Tal ambiente servirá como um apelo para que a população preserve a edificação e seu testemunho cultural, através de um trabalho de sensibilização da sociedade.

Desse modo, conclui-se que é importante uma reflexão e conhecimento sobre o bem a ser preservado, assim como das teorias e Cartas de Restauro, de modo a adaptar o edifício ao novo uso. Assim, a restauração deve ser empreendida de modo a respeitar a construção e os princípios éticos do restauro, valorizando sua forma física original, de igual modo assegurando e ampliando seu tempo de vida útil.

RC: 107028

Disponível em: https://www.nucleodoconhecimento.com.br/arquitetura/centro-deconvivencia 
Além disso, pode-se citar ainda a questão da sustentabilidade, pois a demolição de um edifício, mesmo com uma adequada gestão de resíduos, gera impactos ambientais.

\subsection{CARACTERÍSTICAS ARQUITETÔNICAS DO BEM}

Com o passar do tempo, a fábrica foi perdendo partes de sua estrutura (LUTHER, 2019). O edifício principal da fábrica, apesar de mantido, está abandonado, sofrendo com o agravamento do tempo e de ações de vandalismo, como mostra a Figura 1. Tal fato reforça a importância de uma revitalização.

Figura 1 - Fachada principal da fábrica na Av. Luiz Tarquínio

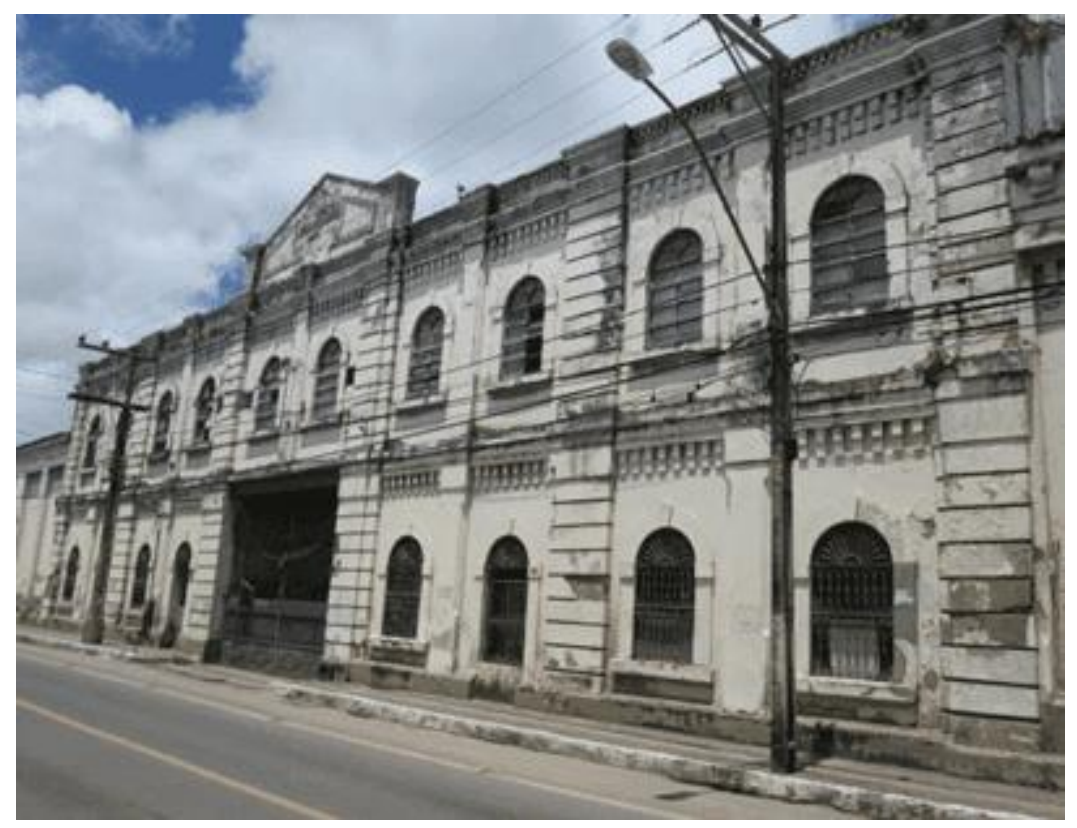

Fonte - Acervo Pessoal.

Um exemplo dessa deterioração é a perda do atracadouro que a Companhia Empório Industrial do Norte possuía. A cobertura dente de serra, que cobria grande parte do terreno, também já não existe mais, assim como grande parte do edifício principal. Os elementos decorativos da fachada já foram quase todos perdidos. Os muros, limites com a Av. Luiz Tarquínio, também tiveram perdas, seja para abertura de acesso de

Disponível em: https://www.nucleodoconhecimento.com.br/arquitetura/centro-deconvivencia 
veículos, ou através do rebaixamento empreendido em um determinado trecho (LUTHER, 2019).

\title{
4. CONDICIONANTES DO PROJETO
}

A seguir serão expostos os fatores que condicionam ou criam condicionamentos para o projeto arquitetônico em suas mais diversas naturezas.

\subsection{CULTURAIS}

No que tange às manifestações socioculturais, temos como grande relevância a Festa da Boa Viagem, tradição cultural e religiosa que acontece nos dias 31 de dezembro e $1^{\circ}$ de janeiro. Segundo Santos et al. (2010), na festa, moradores armam barracas no entorno da Igreja de Nossa Senhora da Boa Viagem e, além da entrega de presentes pelos pescadores na embarcação Galeota do Senhor, ocorre uma procissão marítima, a procissão marítima do Bom Jesus dos Navegantes, levando a imagem do Senhor Bom Jesus dos Navegantes pelas águas da Baía de Todos os Santos, saindo da Basílica de Nossa Senhora da Conceição, no bairro do Comércio, até a igreja da Boa Viagem, passando pelo terreno deste projeto. Assim, a instalação de arquibancadas voltadas para o mar e um deck poderiam servir para a contemplação da procissão e da beleza natural do local.

Quanto ao comportamento social, o livro O caminho das águas em Salvador (2010) destaca,

\begin{abstract}
A Bacia de Itapagipe é uma área que tem vida própria, guardando ainda em muitos locais, um estilo de vida tradicional, sob muitos aspectos, no qual o sentido de pertencimento faz-se presente nas relações com o lugar e com os vizinhos, que ainda mantêm em vários bairros, o hábito de colocar as cadeiras na porta e "prosear" com a vizinhança. (SANTOS et al., 2010, p. 365).
\end{abstract}

Nesse sentido, o Centro poderia aumentar a integração dos vizinhos e se tornar um ponto de encontro para eles, associado a uma maior socialização dos idosos com pessoas de outras gerações.

RC: 107028

Disponível em: https://www.nucleodoconhecimento.com.br/arquitetura/centro-deconvivencia 


\subsection{Físıcos}

O terreno em questão apresenta 20.236,96 $\mathrm{m}^{2}$ de área, sendo que, aproximadamente, $848 \mathrm{~m}^{2}$ são ocupados pelo antigo prédio administrativo da Companhia Empório Industrial do Norte. A testada para a Av. Luiz Tarquínio, única via de acesso, tem 239,22 m, já a parte de fundo compreende 239,02 m lineares, dando acesso à Praia da Boa Viagem e as laterais têm 78,89 m e 90,73 m, como mostra o mapa a seguir (Figura 2). Percebe-se, desse modo, a grande extensão litorânea do terreno, que deve ser explorada.

Figura 2 - Mapa de fisiografia do terreno

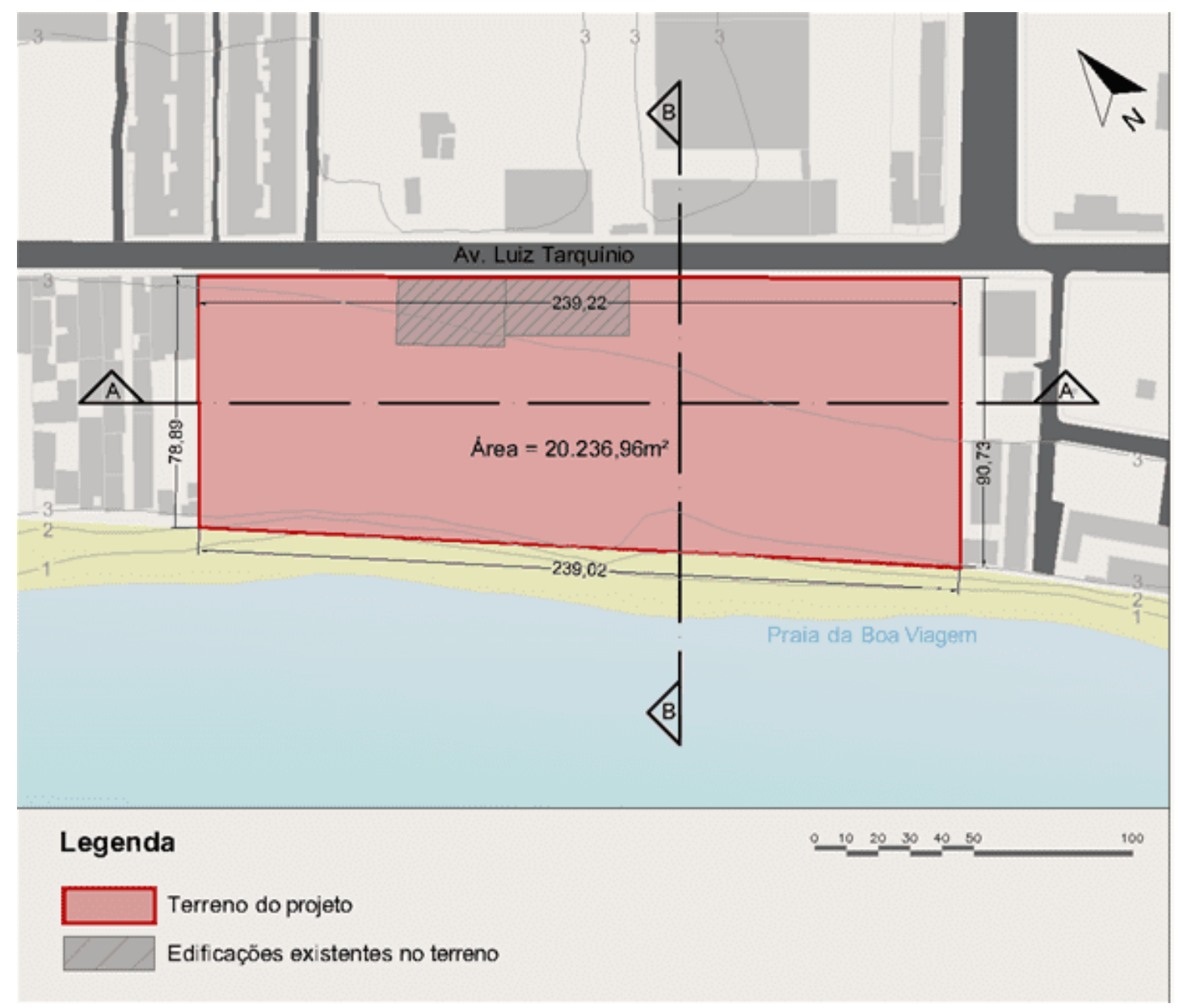

Fonte-Produzido pela autora.

RC: 107028

Disponível em: https://www. nucleodoconhecimento.com.br/arquitetura/centro-deconvivencia 
A Península de Itapagipe tem topografia prioritariamente plana e a topografia do terreno segue o padrão da região, apresentando diferenças de altura de menos de $1 \mathrm{~m}$ dentro do terreno. Isso é extremamente benéfico para o projeto, pois, por conta da perda gradual de mobilidade dos idosos, é de grande importância uma implantação plana que facilite a sua locomoção.

\subsection{QUALIFICAÇÃO DA ESTRUTURA URBANA}

Foi feita uma inspeção técnica no terreno e seu entorno com o objetivo de analisar a qualificação da estrutura urbana da região. Foi notada a presença de corredores com muros extensos, reduzindo a relação público/privado. O terreno em questão apresenta essa configuração em seu limite com a Av. Luis Tarquínio, assim como o terreno em frente a ele, interferindo na sensação de segurança e permeabilidade urbana, além de criar uma barreira visual para a Praia da Boa Viagem. Assim, é uma decisão projetual abrir o terreno para o entorno, através de uma praça, melhorando a relação público/privado e fomentando uma maior integração social da população com o Centro.

Em geral, necessita de atenção a questão das relações sociais, de modo a fomentar a interação entre as pessoas, criar novas opções de áreas de convivência e melhorar as existentes, como o Largo de Roma, também conhecido como praça Irmã Dulce, que está sem manutenção, sofrendo com a ação de vândalos e a presença de lixo. Recomenda-se o aproveitamento do local para o turismo religioso por conta da ligação com o Memorial Irmã Dulce, principalmente após a sua canonização. Desse modo, a Praça Irmã Dulce e a praça que irá ser implantada no terreno deste projeto teriam programa e populações alvo diferentes.

Além disso, a acessibilidade na região está comprometida. Em muitos pontos, não há rampa de acessibilidade nas calçadas, ou, quando há, ela não compreende toda a largura da faixa de pedestre. Foi possível notar alguns pontos com obstáculos à passagem do pedestre, por conta de buracos na calçada e a presença de ambulantes que disputam o espaço com o pedestre.

RC: 107028

Disponível em: https://www.nucleodoconhecimento.com.br/arquitetura/centro-deconvivencia 
Apesar de a região apresentar piso tátil na maior parte de sua extensão, em alguns pontos, ela é interrompida sem sinalização adequada. A adequada instalação desses equipamentos seria de extrema importância para a locomoção de pessoas com problemas de visão ou para a locomoção até o Centro.

Em razão da forma peninsular da região, a mobilidade acaba sendo muito prejudicada. Não há muita integração entre as modalidades de transporte, as linhas de metrô são distantes e as ciclofaixas existentes enfrentam situações precárias. Entretanto, já existe um plano de mobilidade urbana para essa região, com soluções coletivas e nãomotorizadas, oferecendo mais linhas e pontos de ônibus. Além disso, necessita-se da implantação de bicicletários para dar apoio à ciclofaixa já existente.

Deve-se proporcionar também melhores condições aos pedestres, através do melhoramento das calçadas, proporcionando-Ihes o espaço adequado para a sua passagem e implantando rampas de acesso na região. Ademais, as faixas de pedestres devem sofrer manutenção, melhorando a sua visibilidade e alargando as rampas. Além disso, pode-se adotar faixas de travessia de pedestres elevadas em toda a região.

\subsection{AMBIENTAIS}

De acordo com o Zoneamento Bioclimático Brasileiro, especificado na NBR 15220 Parte 3 (ASSOCIAÇÃO BRASILEIRA DE NORMAS TÉCNICAS, 2003), Salvador está na zona bioclimática 8 . Ainda segundo essa norma, nessa região, as aberturas devem ser grandes e sombreadas (área maior que $40 \%$ da área do piso), as paredes e coberturas devem ser leves e refletoras e deve-se utilizar a estratégia de ventilação cruzada permanente.

Em relação a questões especificas do terreno, o primeiro item a ser analisado é a geometria solar. Os mapas das Figuras 3 a 6 mostram a carta solar de Salvador em cada limite do terreno. Desse modo, é possível prever o horário de insolação nas futuras fachadas e a necessidade de sombreamento. As fachadas $39^{\circ} \mathrm{AZ}$ e $129^{\circ} \mathrm{AZ}$

Disponível em: https://www.nucleodoconhecimento.com.br/arquitetura/centro-deconvivencia 
recebem insolação direta pela manhã (Figuras 3 e 4), já as fachadas $222^{\circ} A Z$ e $308^{\circ} A Z$ recebem o Sol à tarde (Figuras 5 e 6). Nessas imagens, a linha azul da carta solar representa o período de insolação no solstício de inverno, a verde nos equinócios e a linha vermelha no solstício de verão.

Figura 3 - Estudo de incidência solar no limite do terreno 39ํAZ

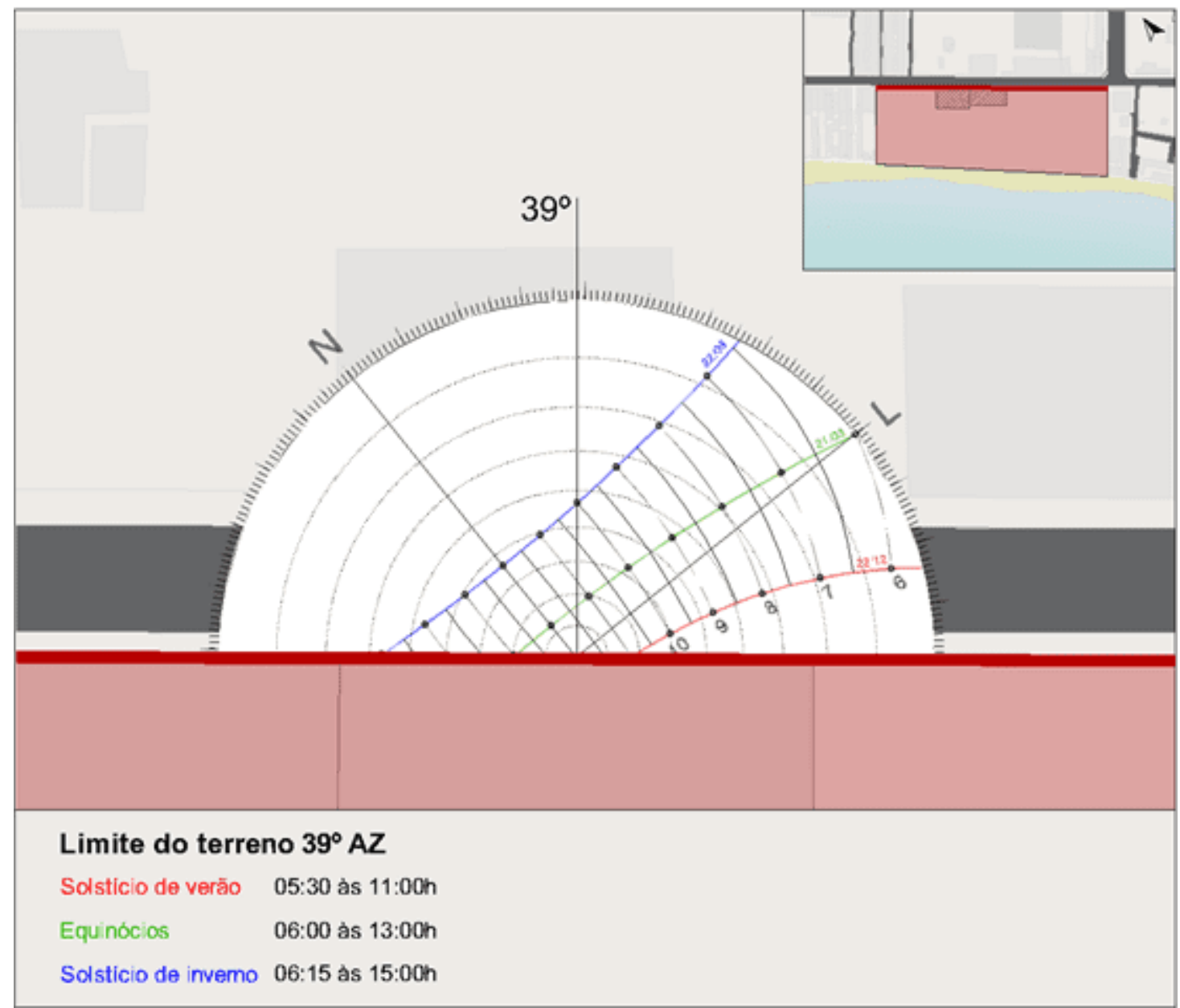

Fonte: Produzido pela autora

RC: 107028

Disponível em: https://www. nucleodoconhecimento.com.br/arquitetura/centro-deconvivencia 
Figura 4 - Estudo de incidência solar no limite do terreno 129 $A Z$

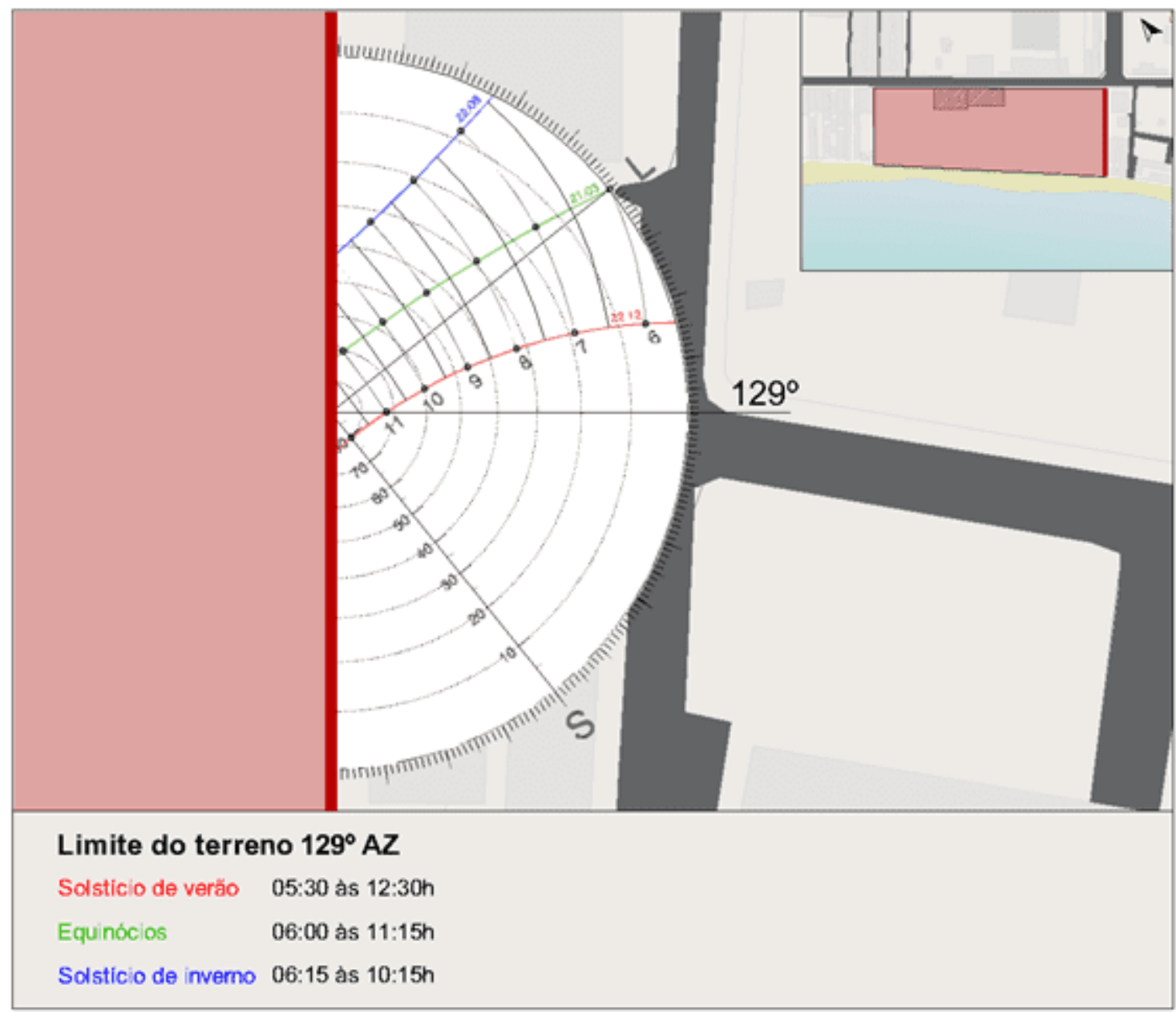

Fonte: Produzido pela autora. 
Figura 5 - Estudo de incidência solar no limite do terreno $222^{\circ} \mathrm{AZ}$

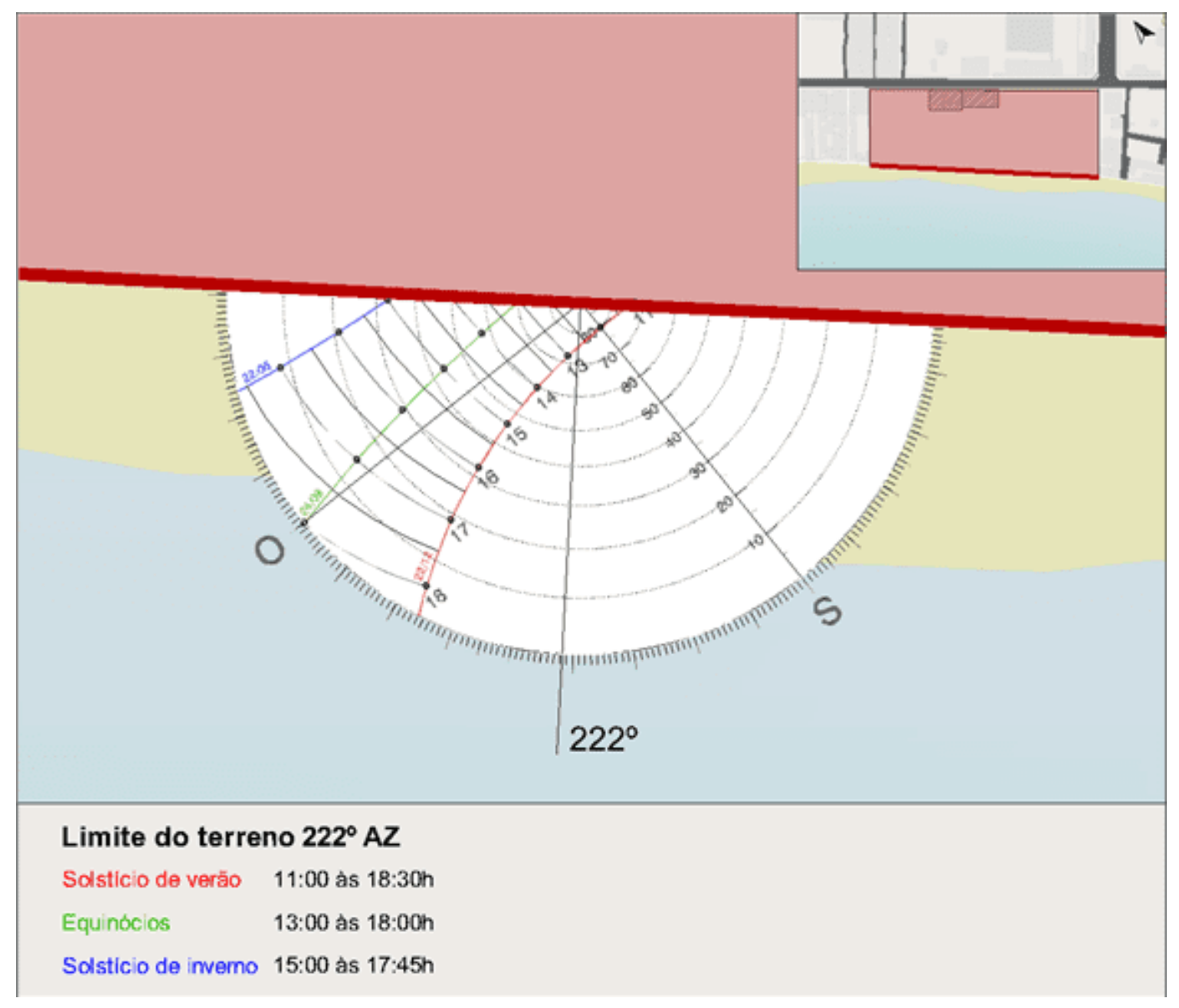

Fonte: Produzido pela autora 
Figura 6 - Estudo de incidência solar no limite do terreno $308^{\circ} A Z$

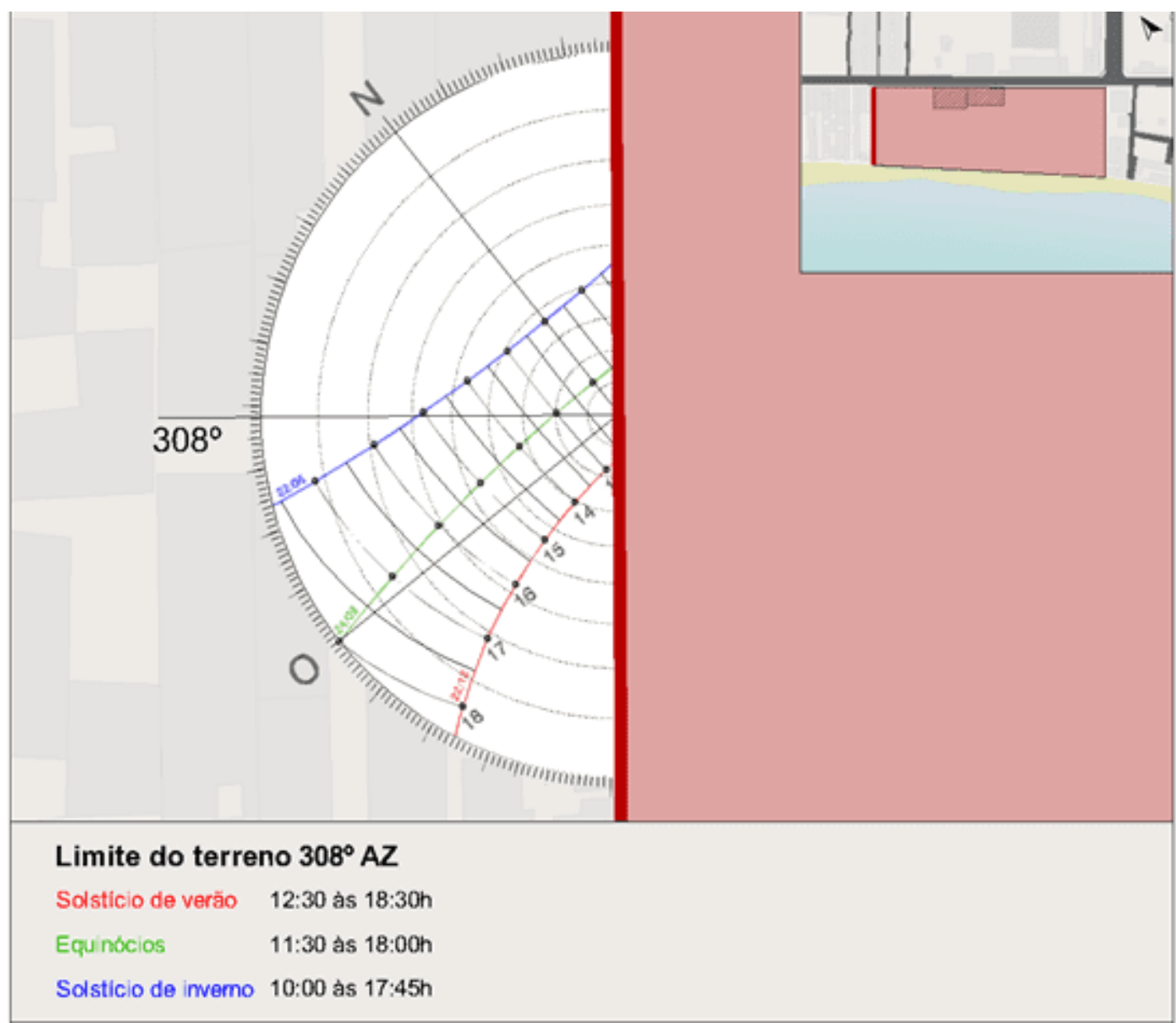

Fonte: Produzido pela autora

Em uma segunda análise, é possível fazer um estudo do sombreamento que os edifícios do entorno provocam no terreno. Como o gabarito de altura do entorno é pequeno, os edifícios não fazem muita sombra no terreno, não sendo necessário pensar em intervenções nesse sentido. De forma ilustrativa, a Figura a seguir (Figura 7) mostra o estudo de sombras para o solstício de verão. 
Figura 7 - Estudo das sombras projetadas para o dia 22 de dezembro, solstício de verão
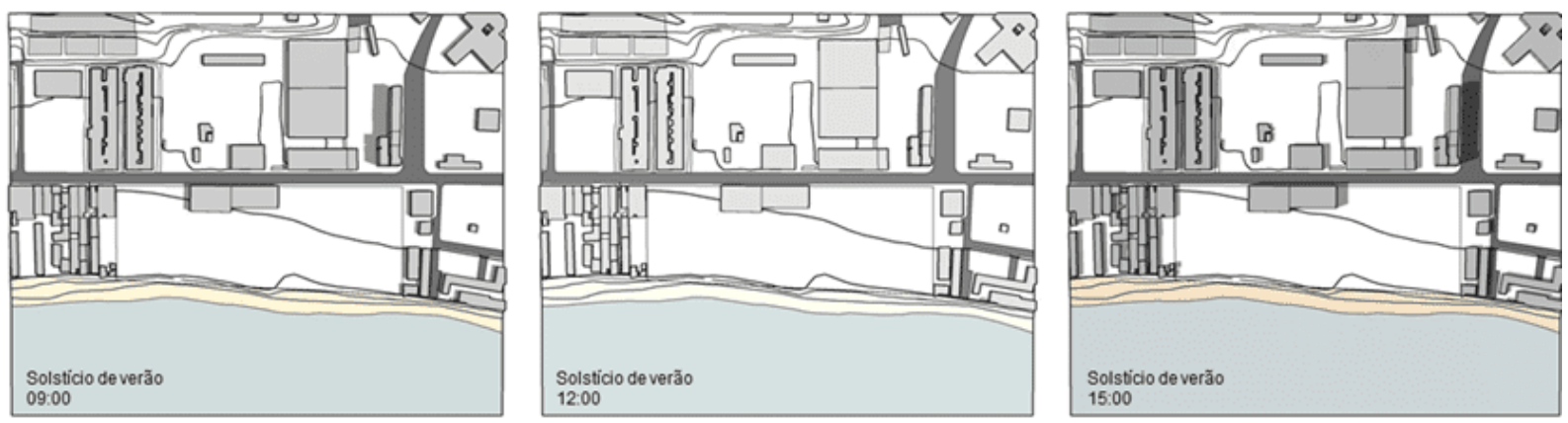

Fonte: Produzido pela autora

Produzidas essas análises, é possível pensar em soluções projetuais que utilizem iluminação natural, aproveitando o potencial do terreno, de modo a reduzir os gastos com energia elétrica, aliviar as tensões e servir como um estímulo ambiental. Segundo Lamberts; Dutra e Pereira (2014), a melhor orientação para a iluminação natural é a norte, por conta da incidência mais contínua de luz solar direta, devendo apenas sombrear as aberturas nessa orientação. A segunda melhor orientação é a sul que, apesar de receber menos luz solar direta, proporcionando menos problemas de ofuscamento, tem boa constância de luz e alta qualidade de luz solar branca fria. Por fim, é preferível que os equipamentos e serviços fiquem nas orientações leste e oeste, pois elas recebem luz solar direta com maior intensidade no verão, dificultando o projeto de proteções solares, que devem considerar ângulos muito baixos de altura solar.

Para a iluminação natural podem ser utilizadas estratégias como pátios e átrios, combinando janelas e aberturas zenitais para o acesso efetivo da luz natural, prateleiras de luz, utilização de quebra-sóis para controlar a incidência solar, além de outras soluções possíveis (LAMBERTS; DUTRA; PEREIRA, 2014).

Ademais, após o sombreamento, a estratégia bioclimática mais importante para o Brasil é a ventilação natural (LAMBERTS; DUTRA; PEREIRA, 2014). O mapa representado na Figura 8 mostra a rosa-dos-ventos da cidade de Salvador aplicada

RC: 107028

Disponível em: https://www.nucleodoconhecimento.com.br/arquitetura/centro-deconvivencia 
ao terreno em estudo. A partir da análise do mapa, é possível perceber que o vento mais frequente durante o outono e inverno vem do Sul e durante a primavera e o verão vem do Sudeste. Como já citado anteriormente, deve-se utilizar a estratégia de ventilação cruzada durante todo o ano, no entanto o condicionamento passivo será insuficiente durante as horas mais quentes (ASSOCIAÇÃO BRASILEIRA DE NORMAS TÉCNICAS, 2003).

Figura 8 - Mapa de estudo de ventilação natural

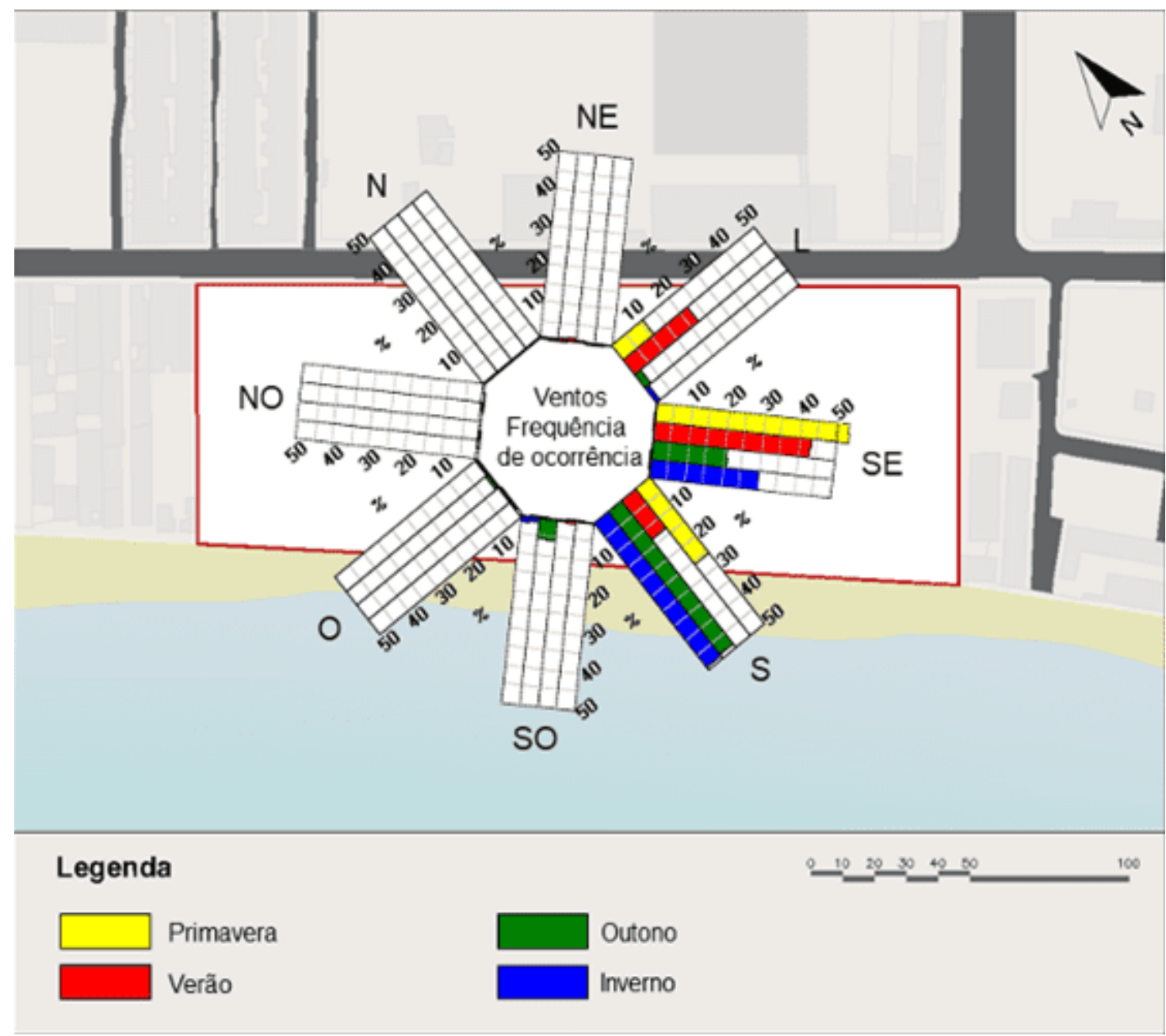

Fonte: Produzido pela autora com rosa-dos-ventos do programa Analysis SOL - AR

Em relação à vegetação da região, pode-se concluir, através da visita de inspeção técnica, que na Av. Luiz Tarquínio há poucas árvores e que a vegetação da região,

Disponível em: https://www.nucleodoconhecimento.com.br/arquitetura/centro-deconvivencia 
em geral, é praticamente inexistente por conta da densidade das edificações. A arborização nas vias públicas poderia ser mais bem trabalhada, encurtando o espaçamento na sua distribuição, através do aumento da vegetação na região e a manutenção das árvores existentes, de modo a gerar maior conforto na caminhada dos pedestres através da sombra dessas árvores.

Por fim, temos o estudo das possíveis fontes de ruído no entorno. Na área ao redor do terreno, as ruas não apresentam uma alta poluição sonora. Na visita de inspeção técnica foi medido o ruído de $62 \mathrm{db}$ na frente do terreno de estudo. Segundo a NBR 10151 (ASSOCIAÇÃO BRASILEIRA DE NORMAS TÉCNICAS, 2000), em ambientes internos, o ruído é diminuído em $10 \mathrm{~dB}$ com a janela aberta e em $15 \mathrm{~dB}$ com a janela fechada. Além disso, a maior fonte de ruído é o uso atual do terreno com a passagem constante de caminhões, portanto, para os usos propostos ao terreno, é de se esperar que esteja de acordo com os parâmetros desejados.

\subsection{LEGAIS}

Foram analisados mapas, quadros e leis da Prefeitura Municipal do Salvador no que concerne ao terreno escolhido. Especialmente, destaca-se o estudo da Lei de Ordenamento do Uso e Ocupação do Solo (LOUOS), lei № 9.148 (SALVADOR, 2016). Alguns parâmetros de ocupação do solo estão indicados no quadro da Tabela 1, já computados de acordo com a área do terreno (20.236,96 m²).

Tabela 1 - Quadro com parâmetros de ocupação do solo

\begin{tabular}{|l|l|l|}
\hline Coeficiente de aproveitamento & Mínimo (CA Mín) & $0,20\left(4.047,39 \mathrm{~m}^{2}\right)$ \\
\cline { 2 - 3 } & Básico (CAB) & $1,00\left(20.236,96 \mathrm{~m}^{2}\right)$ \\
\cline { 2 - 3 } & Máximo (CAM) & $2,00\left(40.473,92 \mathrm{~m}^{2}\right)$ \\
\hline $\begin{array}{l}\text { Índice de ocupação máxima } \\
\text { Índice de permeabilidade mínima }\end{array}$ & & $0,50\left(10.118,48 \mathrm{~m}^{2}\right)$ \\
\hline Recuos mínimos & Frente & $0,30\left(6.071,09 \mathrm{~m}^{2}\right)$ \\
\hline
\end{tabular}

RC: 107028

Disponível em: https://www.nucleodoconhecimento.com.br/arquitetura/centro-deconvivencia 


\begin{tabular}{|l|l|l|}
\hline & Laterais & $1,50 \mathrm{~m}$ \\
\hline Gabarito de altura & Fundo & $2,50 \mathrm{~m}$ \\
\hline
\end{tabular}

Fonte - Produzido pela autora

Desse modo, conclui-se que a implantação deste empreendimento no local em questão é viável, necessitando apenas seguir os parâmetros da norma.

\subsection{PLANEJAMENTO DE SAÚDE}

O presente trabalho foca no atendimento aos idosos, logo, para melhor atendê-los, as edificações devem corresponder às necessidades físico-espaciais mínimas, indicadas na Portaria 73 (BRASIL, 2001), bem como devem estar de acordo com as disposições da NBR 9050 (ASSOCIAÇÃO BRASILEIRA DE NORMAS TÉCNICAS, 2020), da Portaria 810 do Ministério da Saúde (BRASIL, 1989) e da RDC № 283 (BRASIL, 2005). A RDC № 283 (BRASIL, 2005), que define normas de funcionamento para as Instituições de Longa Permanência para Idosos, foi consultada para projetar o setor de habitação e apresenta exigências especificas quanto ao acesso externo, pisos, rampas e escadas, circulações etc.

O setor de saúde, prestará atendimento eletivo de promoção e assistência à saúde dos idosos, englobando as atividades de consulta médica, odontológica, psicológica, de assistência social, de nutrição, de farmácia, de fisioterapia e de terapia ocupacional, além de realizar vigilância nutricional e promover ações de educação para a saúde, através de palestras, demonstrações e treinamento "in loco", campanhas etc. Para o pré-dimensionamento desse setor, foi consultada a base SOMASUS, do Ministério da Saúde (BRASIL, 2011), e a Resolução-RDC № 50, de 21 de fevereiro de 2002, da Agência Nacional de Vigilância Sanitária. Esses documentos informam os equipamentos que devem conter as salas de um atendimento ambulatorial. A base do SOMASUS sugere ainda um layout padrão e informa as características do espaço físico como também a área mínima e média, tipo

RC: 107028

Disponível em: https://www.nucleodoconhecimento.com.br/arquitetura/centro-deconvivencia 
de piso, parede, teto, porta e bancadas, os condicionantes ambientais, como temperatura ideal, nível de iluminamento, condições de ventilação e a infraestrutura necessária às diversas instalações.

\section{CONCEITO}

O conceito do projeto é o bem-estar. Foi baseado na necessidade de promover qualidade de vida aos usuários, de modo a fomentar a autonomia e socialização do idoso, influenciando de forma positiva o seu pensamento em relação ao seu próprio envelhecimento.

\section{PARTIDO ARQUITETÔNICO}

Aqui serão apresentadas as técnicas a serem aplicadas para alcançar os objetivos do projeto e o seu conceito: são as decisões do projeto, pautadas nas necessidades físicas, psicológicas e emocionais dos idosos. Nesse sentido, ratificamos que o bemestar está diretamente relacionado às sensações de conforto. Assim, é prudente pensar em cada uma das variáveis que podem incidir sobre os idosos, de modo a mitigar as limitações impostas pelo envelhecimento.

\subsection{CONFORTO ANTROPODINÂMICO}

Em primeira análise, pode-se pensar no conforto antropodinâmico, que é aquele que se refere aos movimentos requeridos pelas diversas atividades humanas, de modo a atenuar as limitações locomotoras. As estratégias para a promoção desse conforto relacionam-se a uma melhor acessibilidade dos usuários, como trata a NBR 9050 (ASSOCIAÇÃO BRASILEIRA DE NORMAS TÉCNICAS, 2020), levando em consideração a noção de desenho universal e atendendo a todas as pessoas, independente da sua idade, altura ou dificuldade de mobilidade. Assim, a implantação do projeto será prioritariamente térrea. Ademais, os corredores, banheiros e dormitórios serão equipados com barras de apoio, como ajuda adicional para o idoso com dificuldades motoras. 
Outro ponto a considerar é a adequação do entorno do terreno. Será realizada uma intervenção no local para melhorar as condições de acessibilidade e diminuir as possíveis barreiras no caminho. É uma proposta de microacessibilidade para o entorno imediato, com soluções, como rampas, calçadas, sinalização tátil, conexão com faixas de pedestres e rota acessível até o ponto de transporte coletivo, entre outras.

\subsection{ESTÍMULOS SENSORIAIS}

Este projeto busca promover espaços poliatmosféricos, que prezam pelas experiências sensoriais dos usuários. Além disso, visa adotar circulações que difiram de corredores comuns. Essa concepção de poliatimosfera se associa ao conceito de bem-estar de modo a enriquecer essas experiências dos idosos neste Centro, incentivando a descoberta e pensando sempre nas possíveis limitações cognitivas e sensoriais que os idosos podem desenvolver por conta do envelhecimento. Desse modo, as circulações serão espacialmente generosas, dinâmicas e agradáveis, com paradas para descanso, permitindo a socialização do idoso com todos os usuários do Centro.

\subsection{CONFORTO LUMÍNICO}

No que se refere às pessoas idosas, sabe-se que elas precisam de maior nível de iluminação na área de execução de suas tarefas, ou seja, o conforto lumínico não poderá ser suprimido. Sobre essa questão, a NBR 15575 (ASSOCIAÇÃO BRASILEIRA DE NORMAS TÉCNICAS, 2013) sugere que, para promover esse conforto, deve-se garantir o máximo de aproveitamento da luminosidade natural e oferecer uma distribuição uniforme da iluminação dentro dos ambientes.

Ainda nesse sentido, a pesquisadora e arquiteta Ana Lúcia Barbosa, em sua dissertação de mestrado "Conforto e Qualidade Ambiental no Habitat do Idoso" (BARBOSA, 2001), afirma que os contrastes de cores entre paredes, pisos e objetos devem ser otimizados para auxiliar o idoso na identificação dos mesmos. Além disso,

RC: 107028

Disponível em: https://www.nucleodoconhecimento.com.br/arquitetura/centro-deconvivencia 
a autora cita que os idosos são mais sensíveis ao ofuscamento e requerem mais tempo de adaptação às mudanças repentinas de luminosidade.

Com base nisso, a cobertura do setor de atividades tem sua abertura orientada a Sudeste, de modo a captar a luz solar do Leste (nascente) e do Sul, que é aquela que causa menos problemas de ofuscamento, por ter uma boa constância de luz e alta qualidade de luz solar branca fria, sem causar um aumento significativo na temperatura do ambiente, pois não recebe luz solar direta.

\subsection{CONFORTO TÉRMICO}

O conforto térmico expressa a satisfação do usuário com o ambiente térmico em que se encontra e está relacionado à umidade, temperatura, velocidade do ar e radiação solar incidente (FROTA; SCHIFFER, 2001). Nesse sentido, o condicionamento térmico passivo será utilizado para mitigar as dificuldades dos idosos em se adaptar às variações de temperatura. As estratégias para isso são: recuar e proteger janelas e portas para minimizar o ganho de calor dentro dos prédios, com a utilização de grandes varandas; utilizar a ventilação cruzada permanente; a estratégia de efeito chaminé (vide Figura 9 como exemplo); e a utilização de vidros com fator solar para barrar a entrada de calor, porém permitindo a passagem da luz.

RC: 107028

Disponível em: https://www.nucleodoconhecimento.com.br/arquitetura/centro-deconvivencia 
Figura 9 - Perspectiva cobertura do setor de atividades

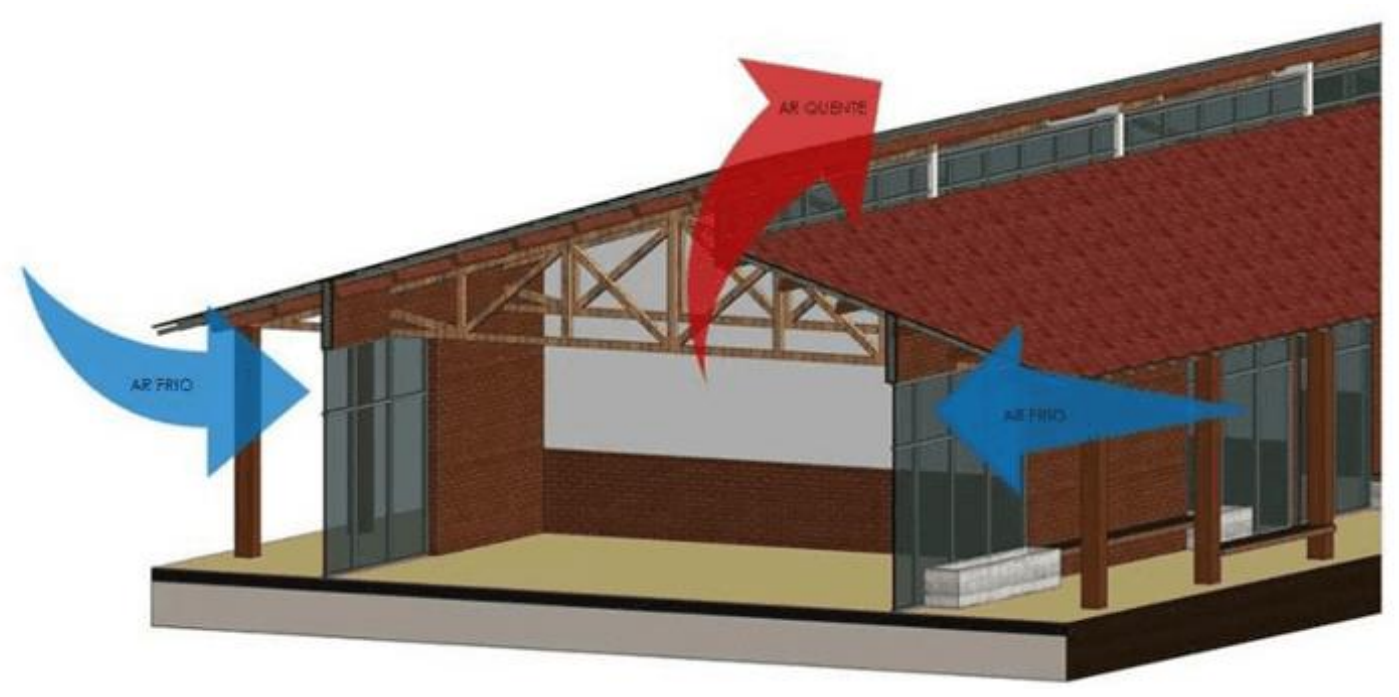

Fonte - Produzido pela autora.

Vale ressaltar que a ventilação natural, além de auxiliar no conforto térmico, auxilia também no combate às infecções e transmissão de doenças através da renovação do ar (FROTA; SCHIFFER, 2001). No entanto, é notório que o condicionamento passivo é insuficiente durante as horas mais quentes do dia, acarretando, assim, a necessidade de utilização de um aparelho de ar-condicionado (ASSOCIAÇÃO BRASILEIRA DE NORMAS TÉCNICAS, 2003). 
Figura 10 - Perspectiva do projeto mostrando pergolados cobertos e descobertos

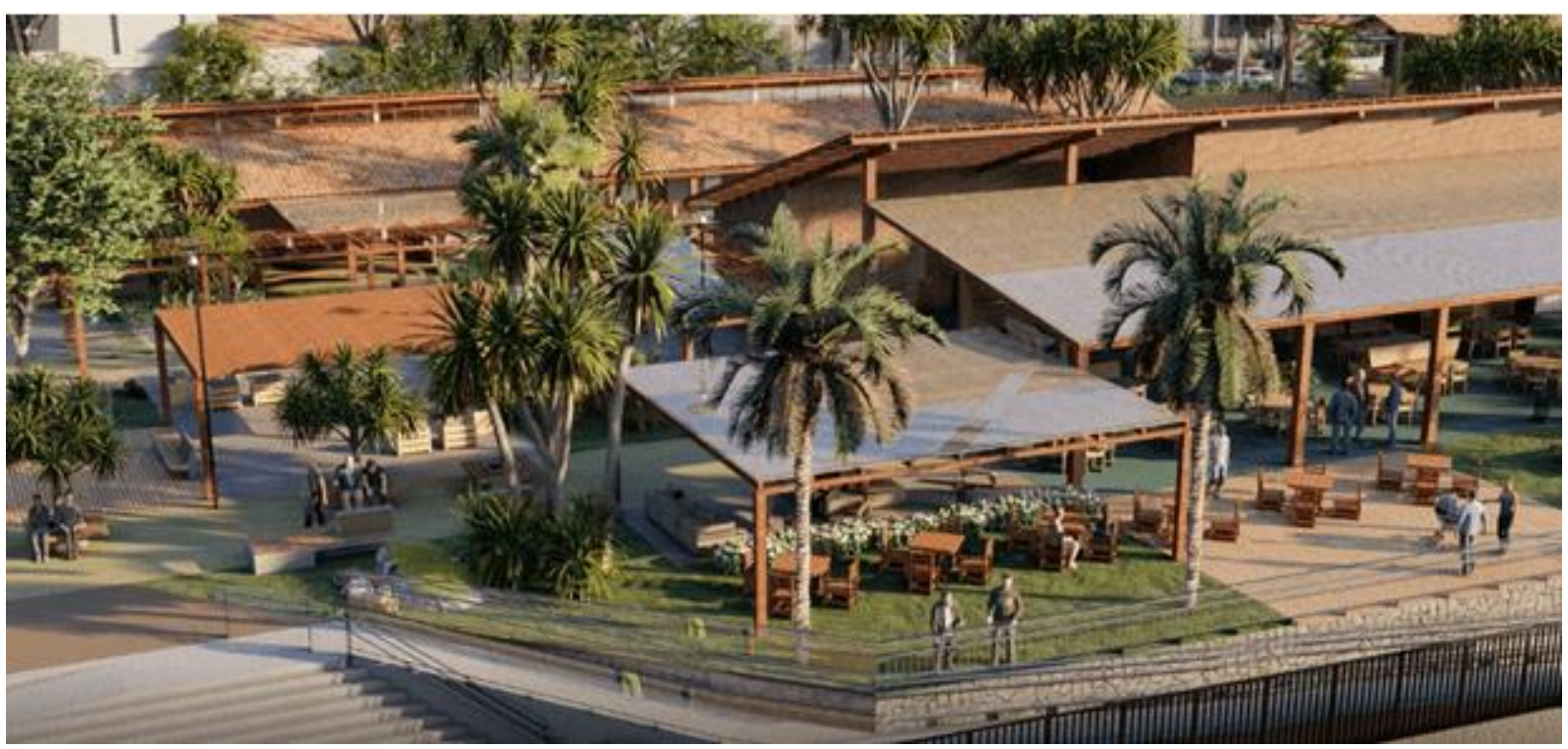

Fonte - Produzido pela autora.

A Figura 10 é uma perspectiva do projeto que apresenta espaços que alternam condições de sol e sombra através do uso de pergolados. Nesse sentido, a arquiteta Me. Ana Lúcia Barbosa (2001) afirma que a criação de espaços alternativos com sol (pátios e jardins) e sombra (varanda e espaços arborizados) aumentam as chances de se encontrar um local confortável nos diferentes horários do dia e épocas do ano, o que é extremamente benéfico para os idosos.

Adicionalmente, serão também plantadas mais árvores para a promoção do conforto térmico e estético. Para isso, serão feitos plantios de espécies vegetais nativas. Este ponto se relaciona com o que será proposto a seguir.

\subsection{DESIGN BIOFÍLICO E SUSTENTABILIDADE}

Seguindo nesta linha de promoção do bem-estar, outro fator importante é a promoção do contato com a natureza, o que traz benefícios para a saúde do corpo e da mente, promovendo um equilíbrio físico e emocional. Nesse sentido, como será utilizada a iluminação natural, existirão muitas aberturas para a parte exterior do Centro que, por

Disponível em: https://www.nucleodoconhecimento.com.br/arquitetura/centro-deconvivencia 
sua vez, terá um paisagismo planejado de modo a deixar o ambiente mais agradável. Essa visão do exterior é ainda mais importante para os idosos com problemas de locomoção, que permanecem grande parte de seu tempo em ambientes internos, conforme afirma a arquiteta Me. Ana Lúcia Barbosa em sua dissertação (2001).

Além disso, existem diversos benefícios para os idosos no contato diário com a natureza, como a respiração de ar mais puro, a exposição controlada ao sol e a disponibilidade de espaço para caminhar, exercitar-se e conviver com outras pessoas (BARBOSA, 2001). Desse modo, a praça proposta para o local será extremamente positiva nesse sentido.

A partir da incorporação da natureza ao projeto arquitetônico, surge a ideia do design biofílico, que será amplamente utilizado nesse projeto através de jardins internos e externos, além de materiais e acabamentos que exponham as características naturais do ambiente. O recurso de parede verde, ou jardins verticais, também será utilizado, trazendo a sensação de camuflagem, proteção e apego ao meio ambiente. No subsetor de saúde, por exemplo, o design biofílico propõe uma visão mais humanizada, com a utilização da vegetação para auxiliar na promoção da saúde.

Para finalizar, serão utilizados materiais de boa durabilidade e baixa necessidade de manutenção, simplificando também os acabamentos, prezando por deixá-los sem revestimento ou pintura sempre que possível, de modo a otimizar o desempenho ambiental.

\section{O PROJETO}

A implantação do projeto foi feita tomando como ponto de partida o mar e o edifício existente, a administração da antiga Companhia Empório Industrial do Norte, que foi preservada, e considerando o valor histórico da edificação. Por outro lado, as estruturas que não são originais da antiga fábrica, onde atualmente funcionam depósitos e um banheiro, serão retirados, abrindo espaço para a praça proposta no terreno.

RC: 107028

Disponível em: https://www.nucleodoconhecimento.com.br/arquitetura/centro-deconvivencia 
Figura 11 - Perspectiva do terreno com a pré-existência em destaque

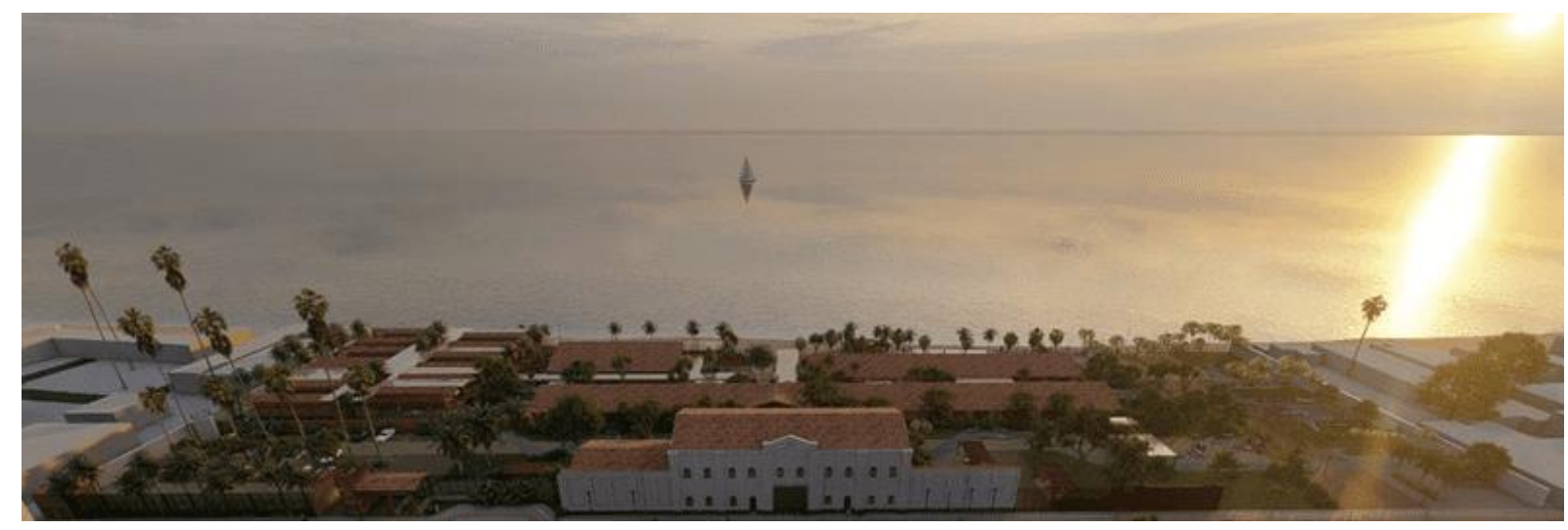

Fonte-Produzido pela autora.

Seguindo a arquitetura do casarão (Figura 11), os edifícios novos seguem uma volumetria mais retilínea e apresentam uma estética pautada no uso de materiais naturais. Os setores, apesar de diferentes, se conversam, falam a mesma linguagem. Todos têm coberturas que buscam promover um melhor aproveitamento dos condicionantes naturais, utilizando-se grandes esquadrias para este fim e para aumentar a relação dos ambientes internos com o exterior, além de ser usado o tijolo maciço cerâmico, como material que tem características naturais, não necessitando de pintura e outros acabamentos, o que possibilita diversas formas de assentamentos, promovendo uma diversidade de aplicações, sem desconfigurar a unidade estética do todo. Também, de modo a não competir com o edifício existente, as construções novas se encontrarão recuadas em relação ao que sobrou da antiga fábrica, como mostra a planta de layout geral da Figura 12. 
Figura 12 - Planta de layout geral

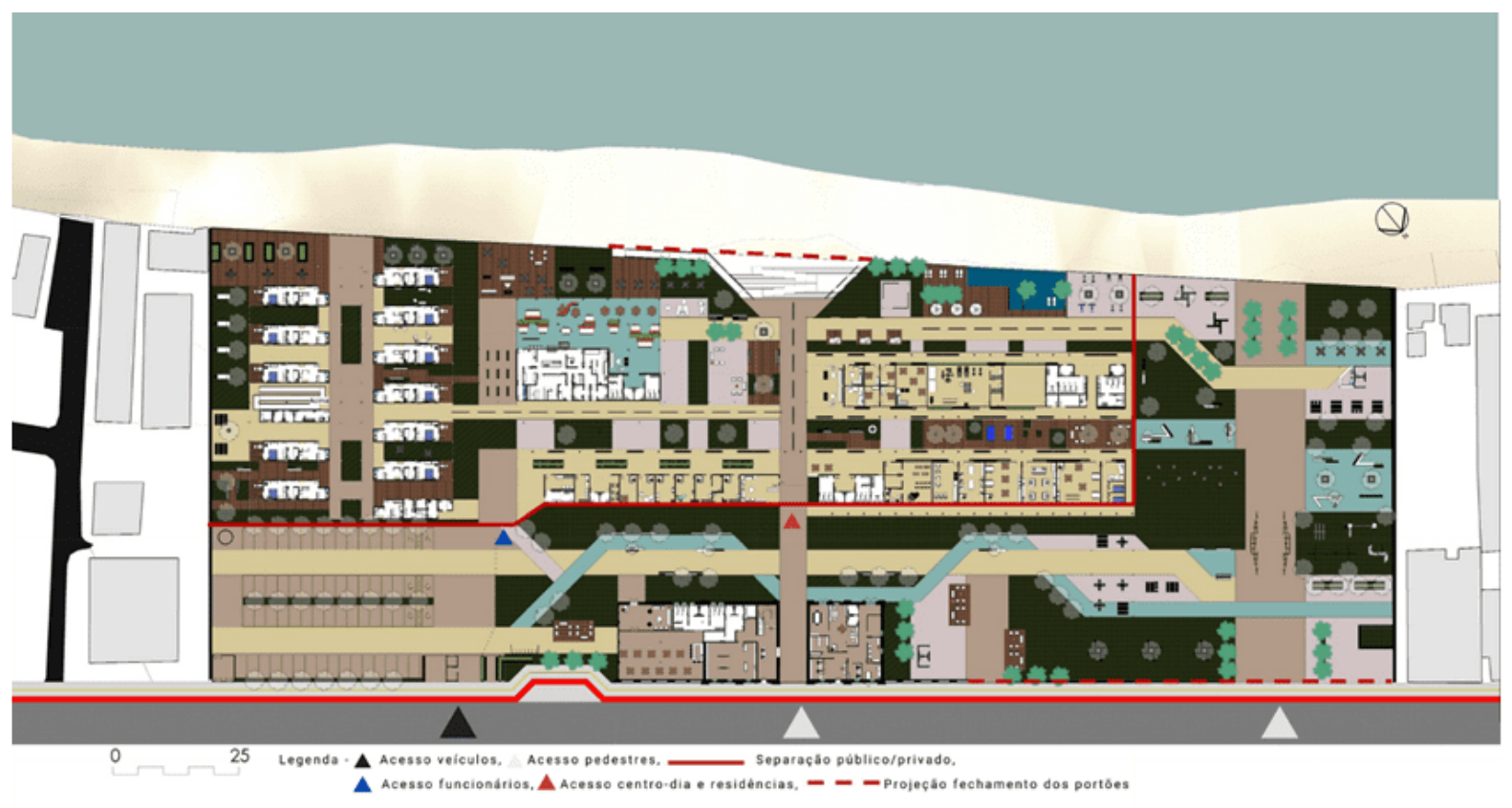

Fonte-Produzido pela autora.

\subsection{SETOR DA PRÉ-EXISTÊNCIA}

O casarão restaurado terá o importante papel de porta de entrada para o Centro e abrigará o subsetor de administração, eventos, biblioteca, e Memorial da Boa Viagem, conforme ressaltam as Figuras 13, 14 e 15. Vale ressaltar que o salão de eventos poderá ser alugado para outros fins cuja renda poderá ser revertida para a manutenção do Centro.

RC: 107028

Disponível em: https://www.nucleodoconhecimento.com.br/arquitetura/centro-deconvivencia 
Figura 13 - Planta de layout pré-existência térreo

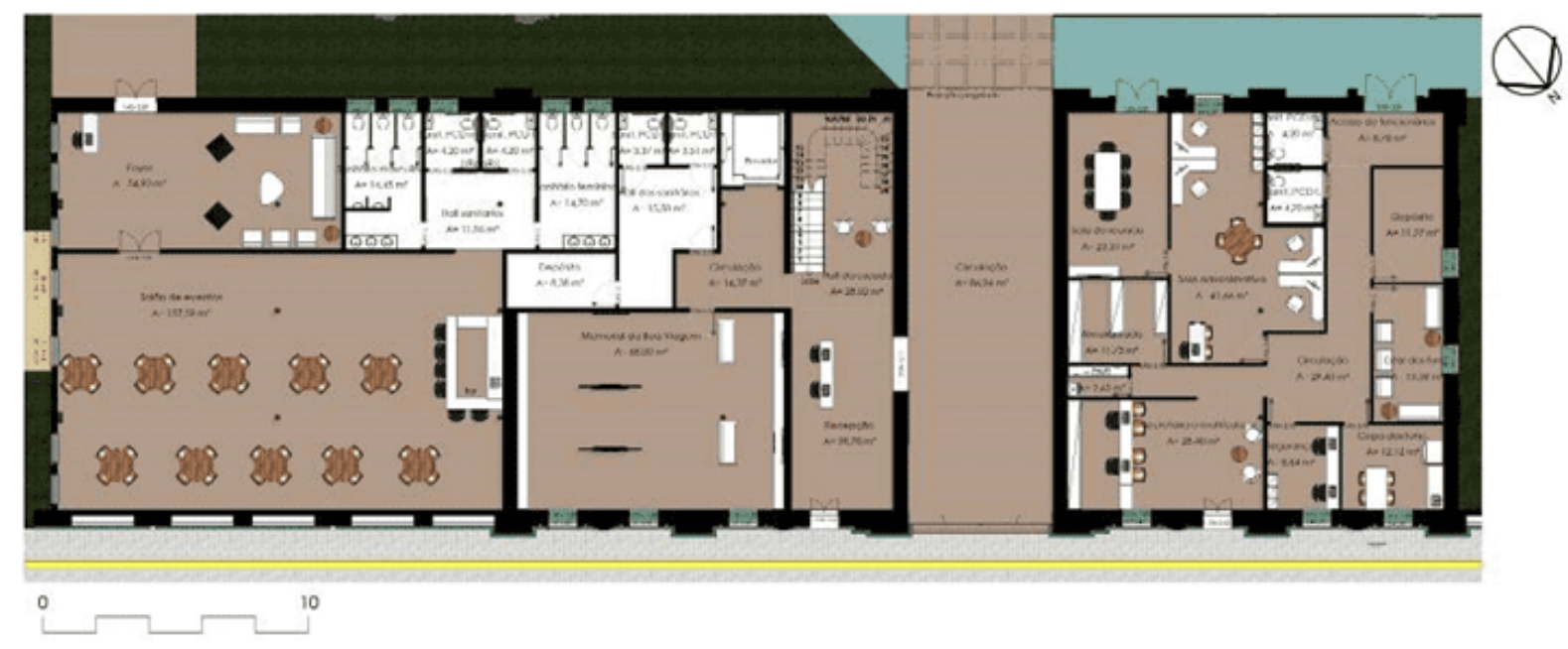

Fonte - Produzido pela autora

Figura 14 - Planta de layout pré-existência 1ํ pavimento

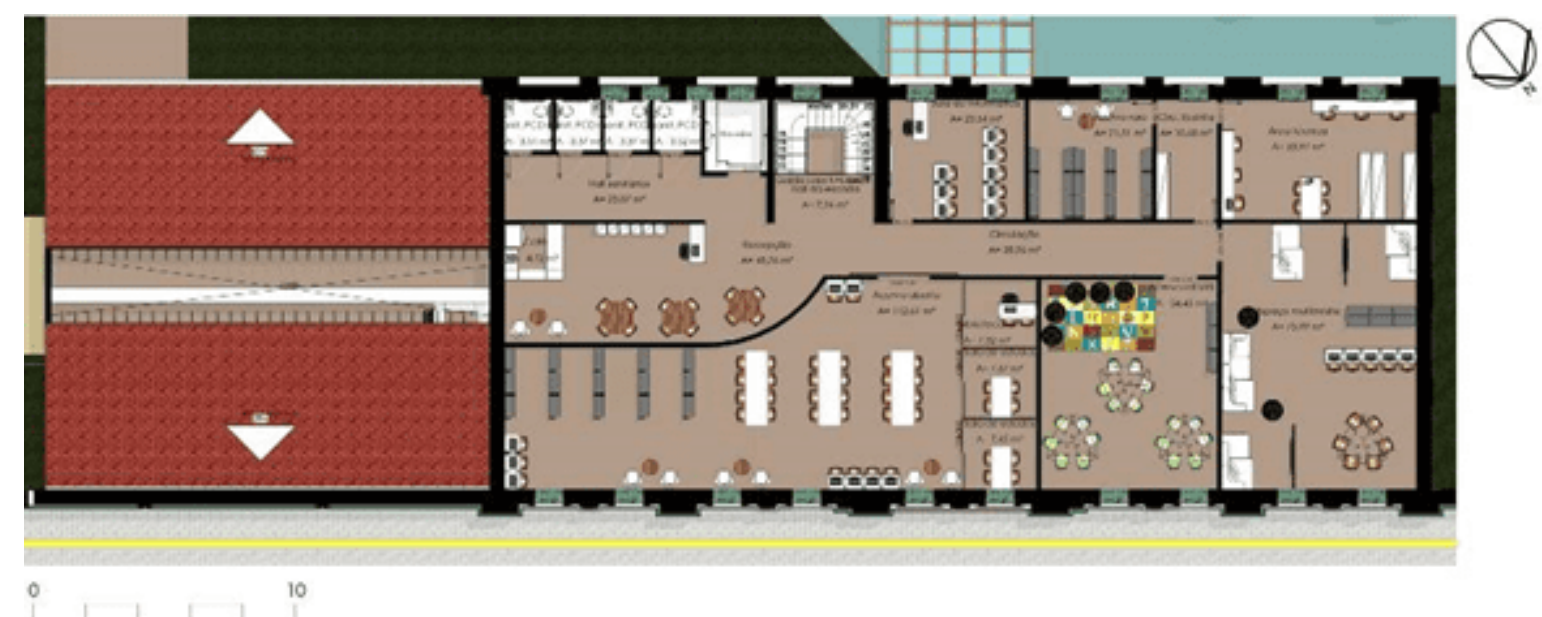

Fonte - Produzido pela autora.

RC: 107028

Disponível em: https://www.nucleodoconhecimento.com.br/arquitetura/centro-deconvivencia 
Figura 15 - Perspectiva mostrando a recepção do setor de atividades e pergolado paramétrico que conecta este setor ao da pré-existência

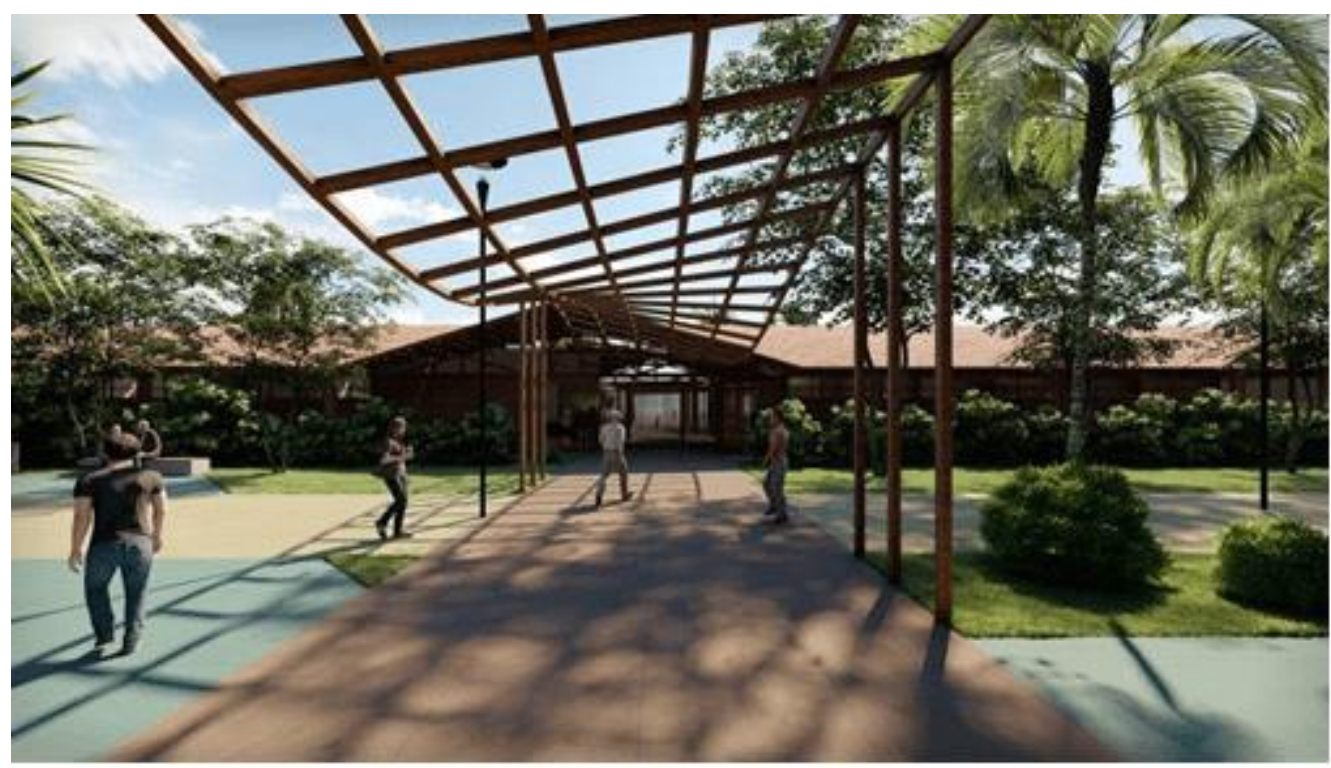

Fonte-Produzido pela autora

Através da Figura 16, é possível notar as alterações feitas na fachada existente, retirando grande parte do atual muro e instalando um gradil que permite a permeabilidade visual.

Figura 16 - Fachada frontal na Av. Luiz Tarquínio

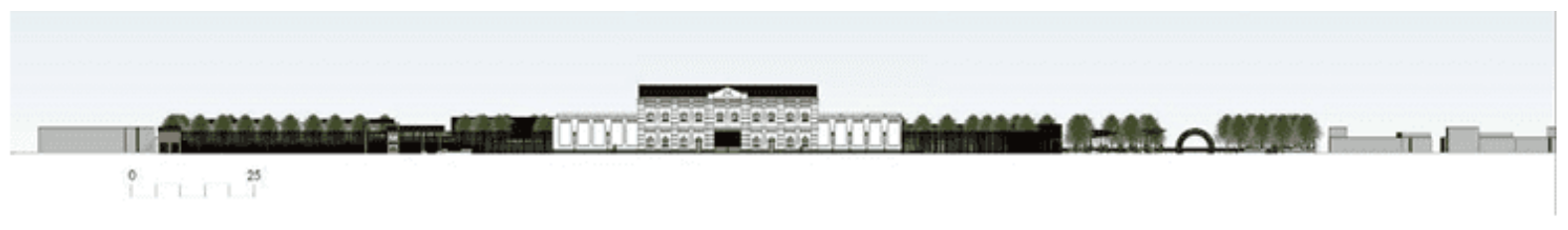

Fonte - Produzido pela autora

\subsection{SETORES DE ATIVIDADES E ALIMENTAÇÃO}

O setor de atividades teve sua implantação realizada de modo longitudinal em relação ao mar, de maneira a aproveitar sua relação com a Baia de Todos os Santos e seguir o padrão da poligonal do terreno. Nesse setor, foram utilizadas grandes varandas que

RC: 107028

Disponível em: https://www.nucleodoconhecimento.com.br/arquitetura/centro-deconvivencia 
dão acesso às salas e promove um sombreamento das vedações, reduzindo a temperatura interna, conforme demonstra a Figura 17.

Figura 17 - Planta de layout dos setores de atividades e alimentação

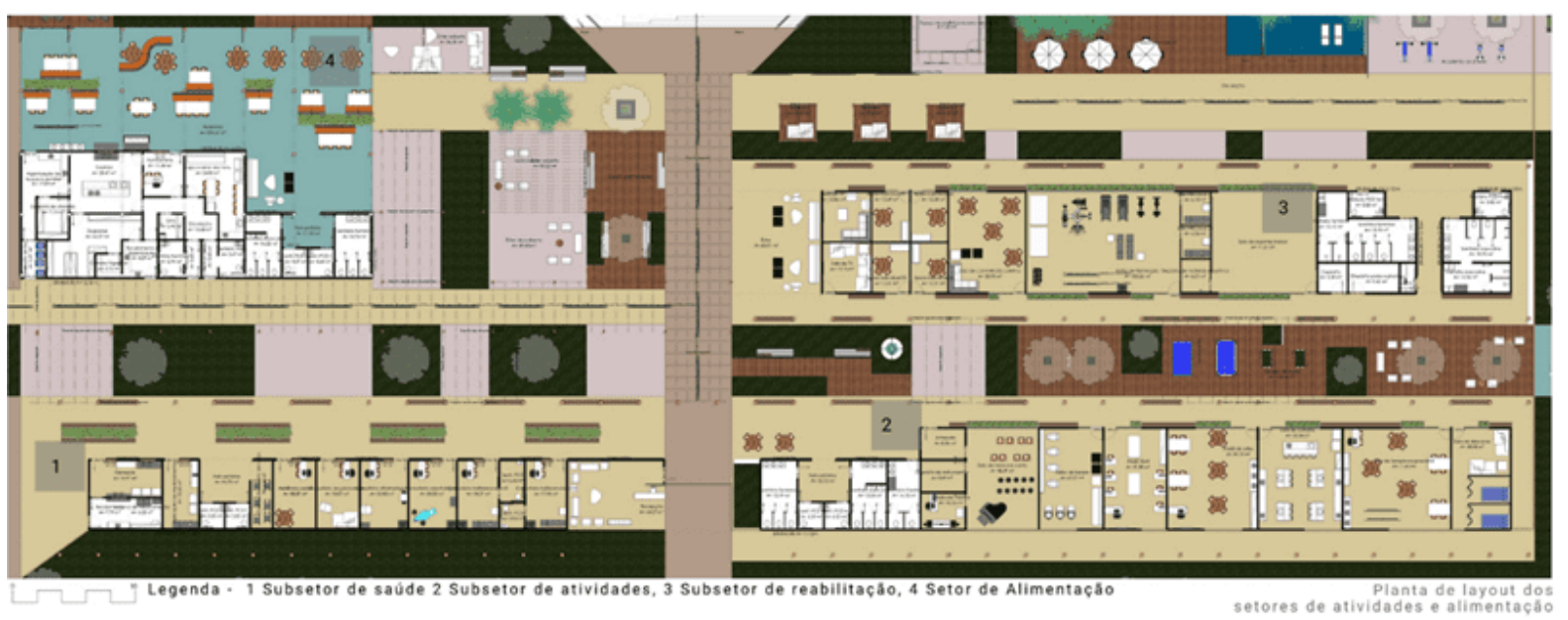

Fonte - Produzido pela autora.

A Figura 18 mostra a perspectiva lateral do setor de atividades, ressaltando a separação com a praça pública e dando destaque à assimetria da cobertura que promove ventilação e iluminação natural.

Figura 18 - Perspectiva lateral do setor de atividades

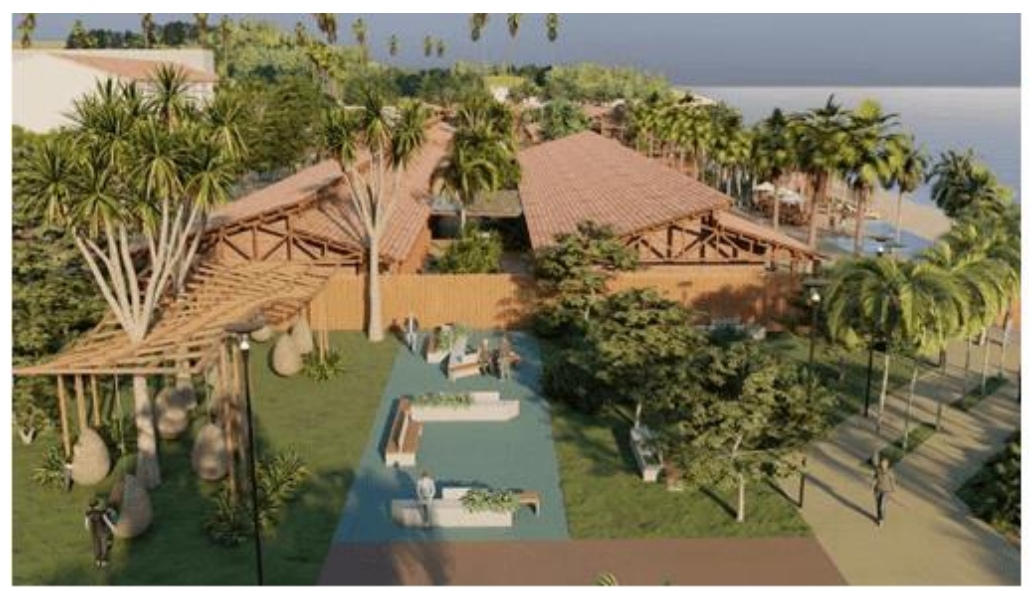

Fonte-Produzido pela autora.

RC: 107028

Disponível em: https://www.nucleodoconhecimento.com.br/arquitetura/centro-deconvivencia 
O subsetor de saúde foi desenhado de modo a ser um espaço mais "leve" para esses idosos, com ambientes para socialização, já que a ida, por exemplo, a uma consulta médica para alguns idosos pode ser um momento de estresse e ansiedade. Para isso, sua varanda possui bancos ajardinados para a socialização das pessoas e apresenta jardins entre esse subsetor e o setor de alimentação. Seu programa envolve também atividades pensadas na melhora de aspectos psicológicos dos pacientes, como a sala de psicologia e a sala de assistência social, além de uma ampla sala de terapia ocupacional no subsetor de atividades que visa promover atividades que melhorem a autonomia dos pacientes, além de estimular a socialização deles nas sessões, reforçando o que é proposto nos objetivos deste projeto.

O acesso à praia será feito através de uma escada integrada a uma rampa, conforme Figura 19. Ela poderá servir de arquibancada para contemplação do mar ou da procissão marítima do Bom Jesus dos Navegantes.

Figura 19 - Perspectiva do acesso à praia

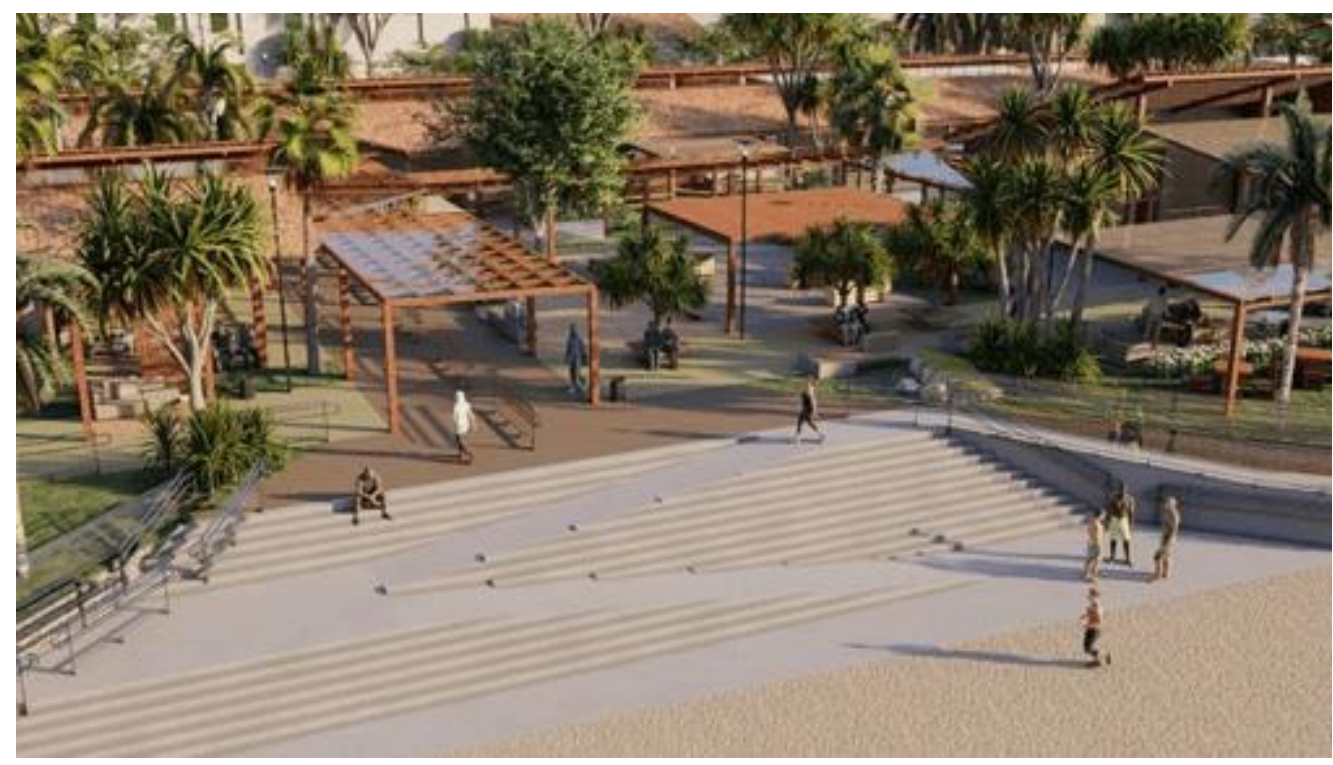

Fonte-Produzido pela autora.

Disponível em: https://www.nucleodoconhecimento.com.br/arquitetura/centro-deconvivencia 
Já o setor de alimentação foi implantado na região central do terreno, de modo que ficasse próximo aos outros setores, atendendo os idosos da ILPI e os outros idosos que optarem por passar o dia no Centro.

Figura 20 - Perspectiva posterior do setor de atividades com destaque para piscina e espaço inter-religioso e de meditação à direita

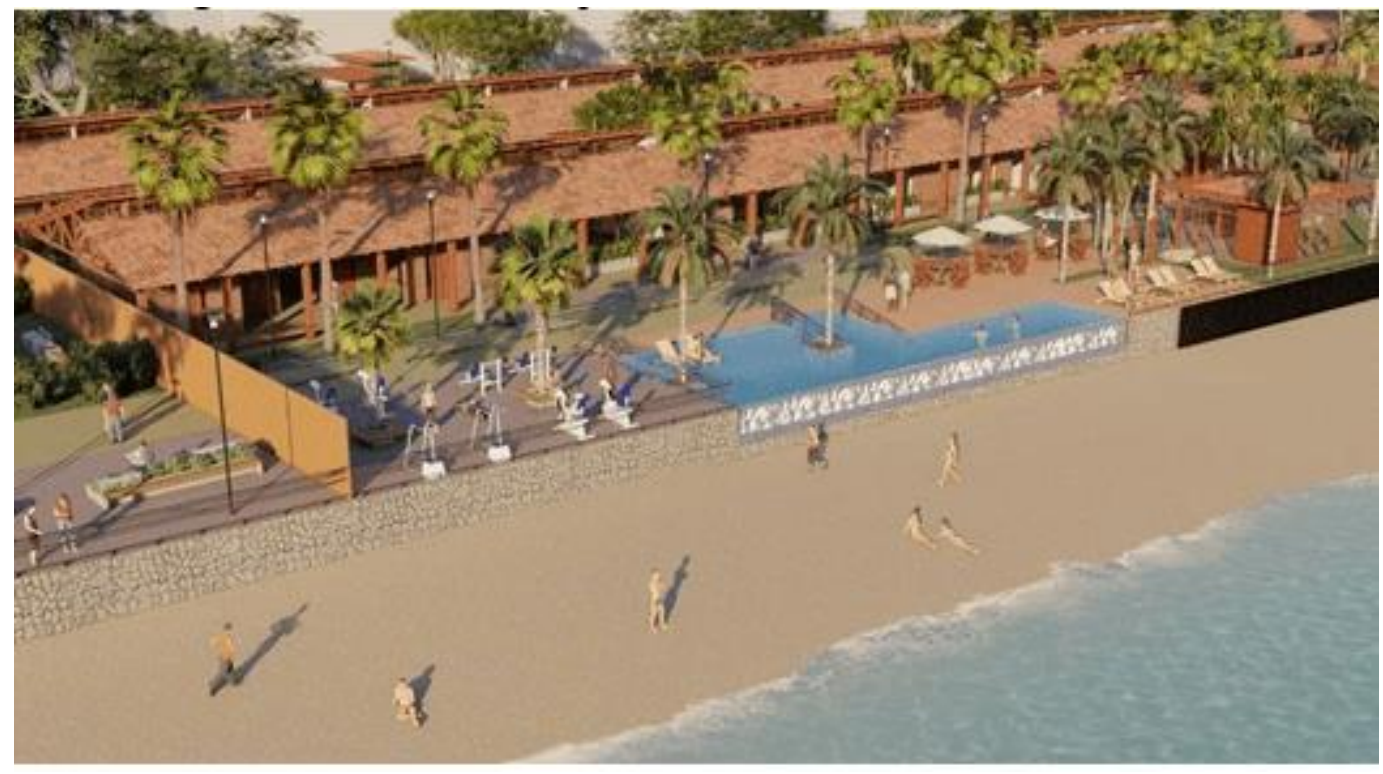

Fonte-Produzido pela autora.

RC: 107028

Disponível em: https://www.nucleodoconhecimento.com.br/arquitetura/centro-deconvivencia 
Figura 21 - Perspectiva da piscina e espaço inter-religioso e de meditação

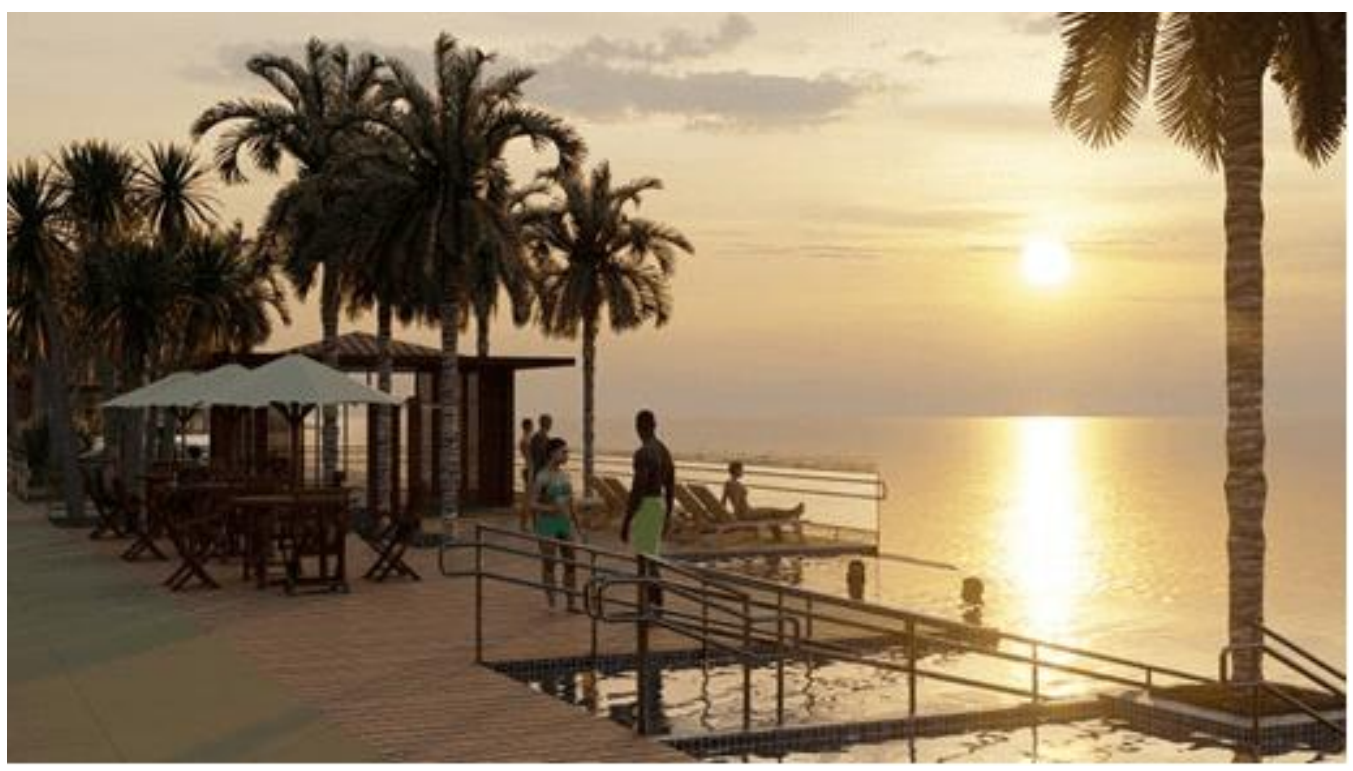

Fonte - Produzido pela autora

As Figuras 20 e 21 apresentam a piscina, que foi projetada com borda infinita com o objetivo de proporcionar a sensação de amplitude e extensão do mar. Além disso, o espaço inter-religioso e de meditação tem uma visão privilegiada da beleza natural do local, possuindo grandes esquadrias para permitir a contemplação.

\subsection{SETOR DE HABITAÇÃO}

O setor de habitação foi desenvolvido a partir do conceito de poliatmosfera e biofilia, alternando uma volumetria de espaços cheios, vazios, pavimentados, gramados, cobertos e descobertos, como mostram as Figuras 22 e 23 . Seu formato traz o arquétipo de casa com o objetivo de aflorar uma sensação de pertencimento, para que vire um verdadeiro lar aos residentes, além disso, esse formato permite a fácil identificação do setor (Figura 24). 
Figura 22 - Planta de layout habitação térreo

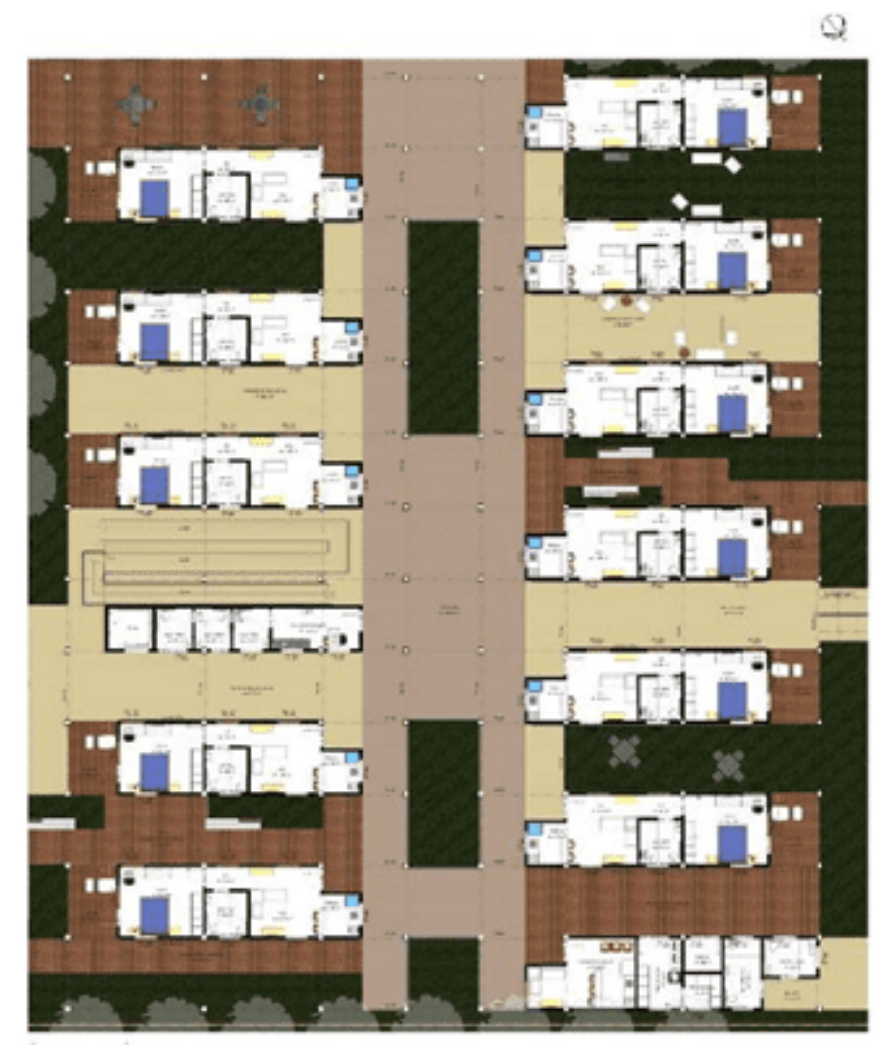

Fonte - Produzido pela autora. 
Figura 23 - Planta de layout habitação $1^{\circ}$ pavimento

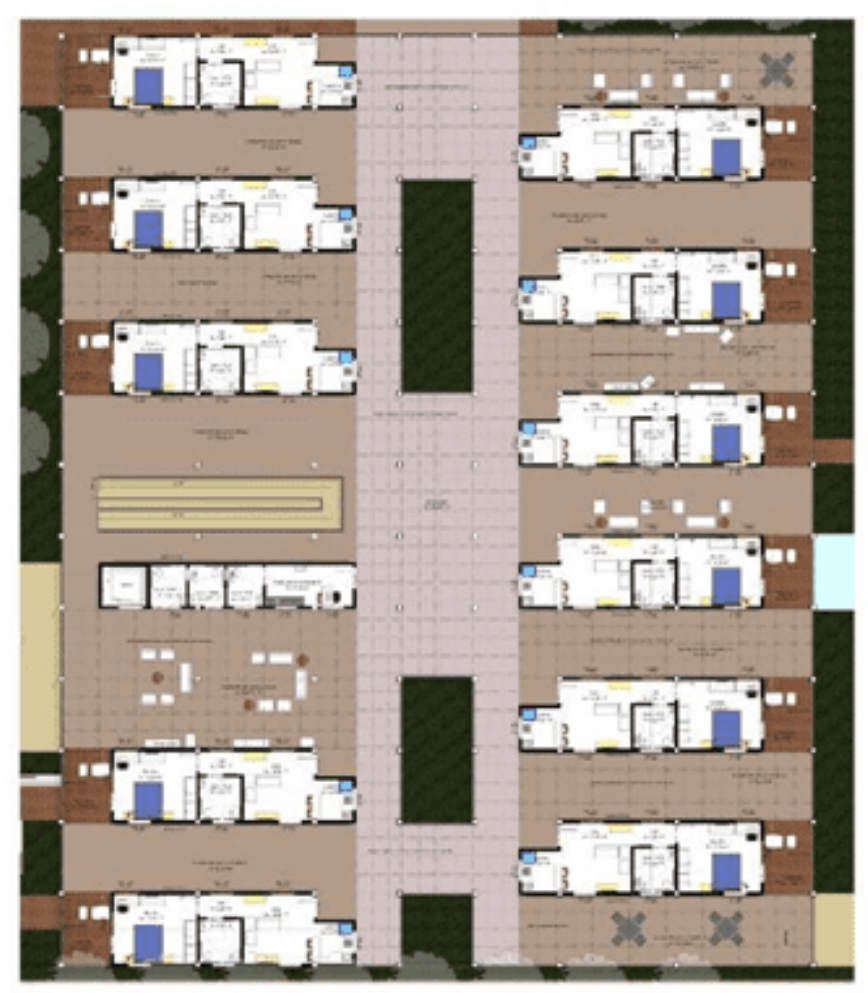

Fonte - Produzido pela autora

Figura 24- Fachada lateral do setor de habitação

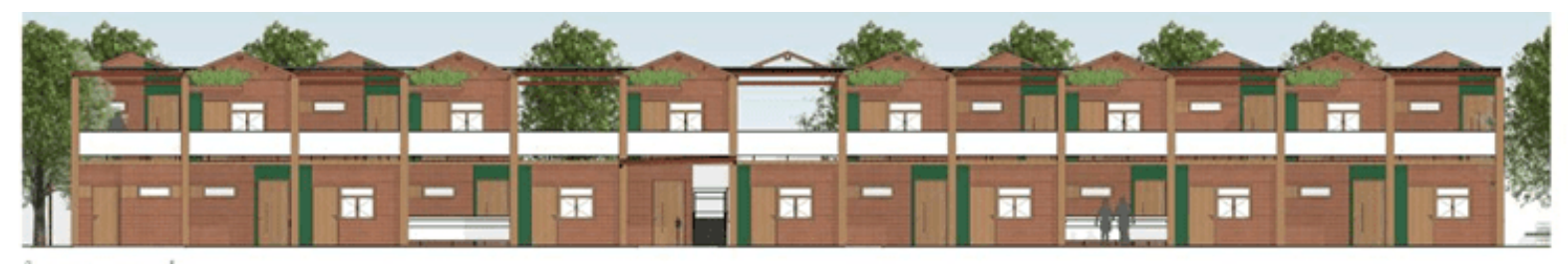

Fonte - Produzido pela autora.

A Figura 25 mostra o layout do apartamento modelo através de uma perspectiva isométrica. É possível perceber que o espaço foi planejado para ser acessível aos idosos. 
Figura 25 - Perspectiva esquemática do apartamento modelo

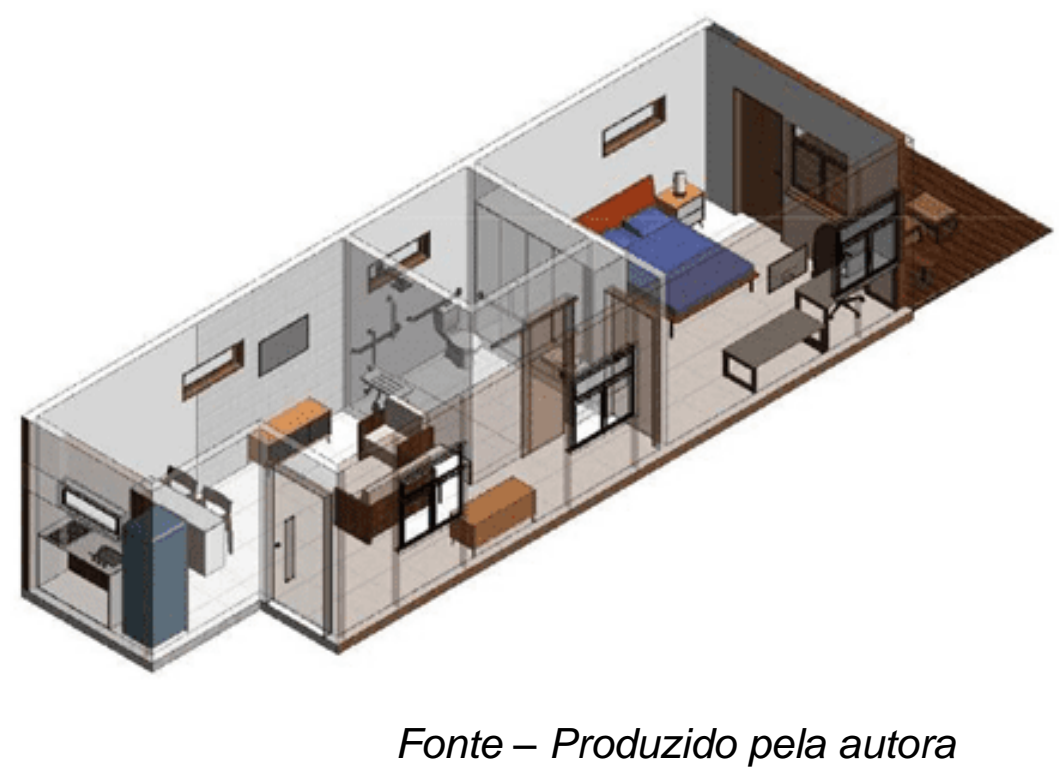

\subsection{PRAÇA PÚBLICA}

É uma decisão projetual abrir o terreno para o entorno, através de uma praça, fomentando uma maior integração social da população com o Centro, tornando-o um centro atrativo para toda a comunidade. Na praça, os espaços serão pensados de modo a promover uma integração intergeracional, contando com área de jogos, parque infantil, café e espaços de socialização e contemplação (Figuras 26 e 27). À noite, os portões serão fechados para maior segurança dos habitantes (Figura 28). 


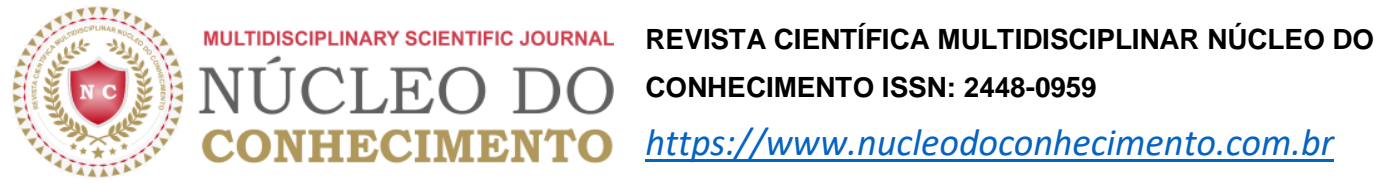

Figura 26 - Perspectiva praça pública

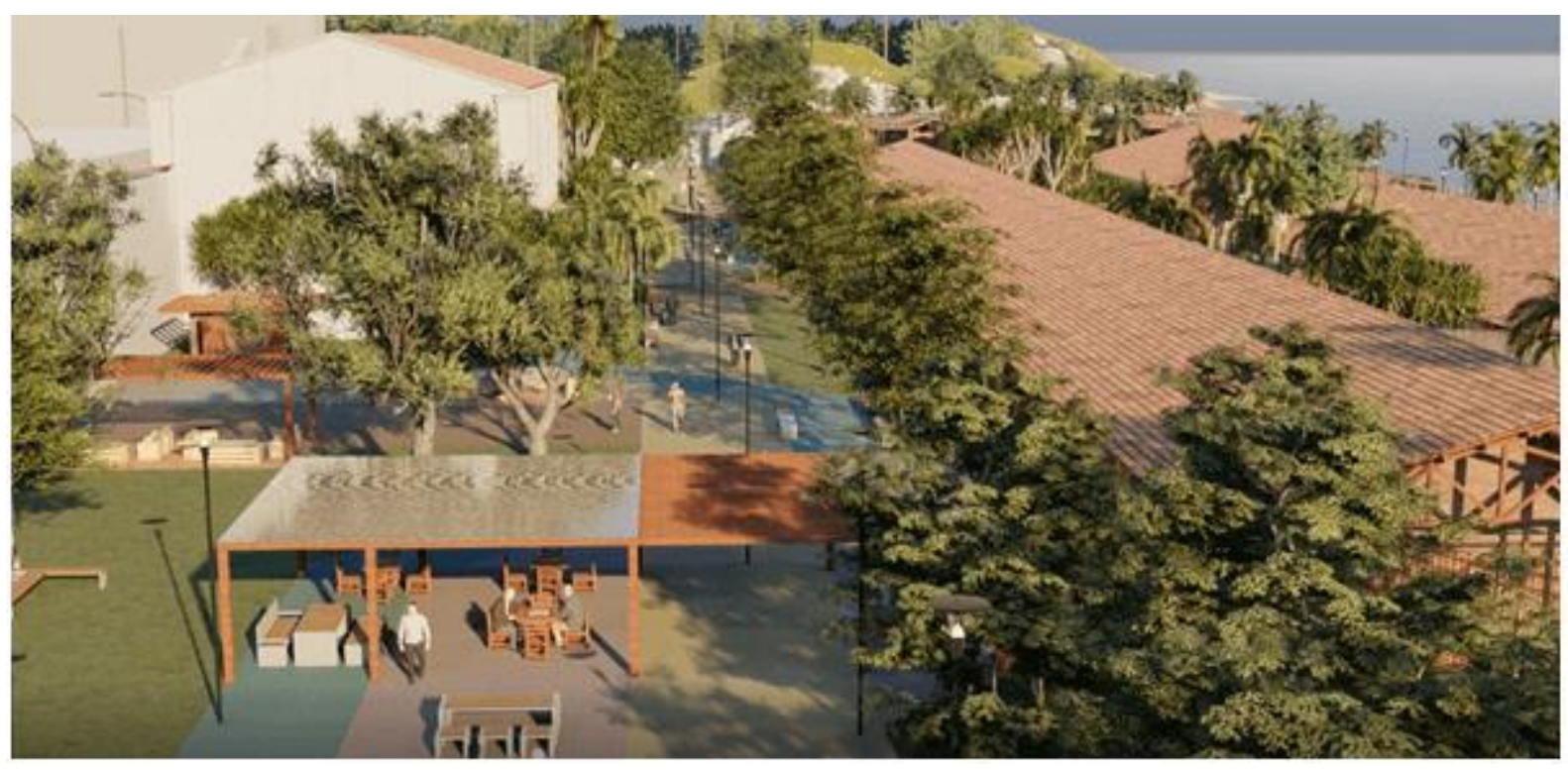

Fonte - Produzido pela autora

Figura 27 - Perspectiva do túnel paramétrico na praça pública

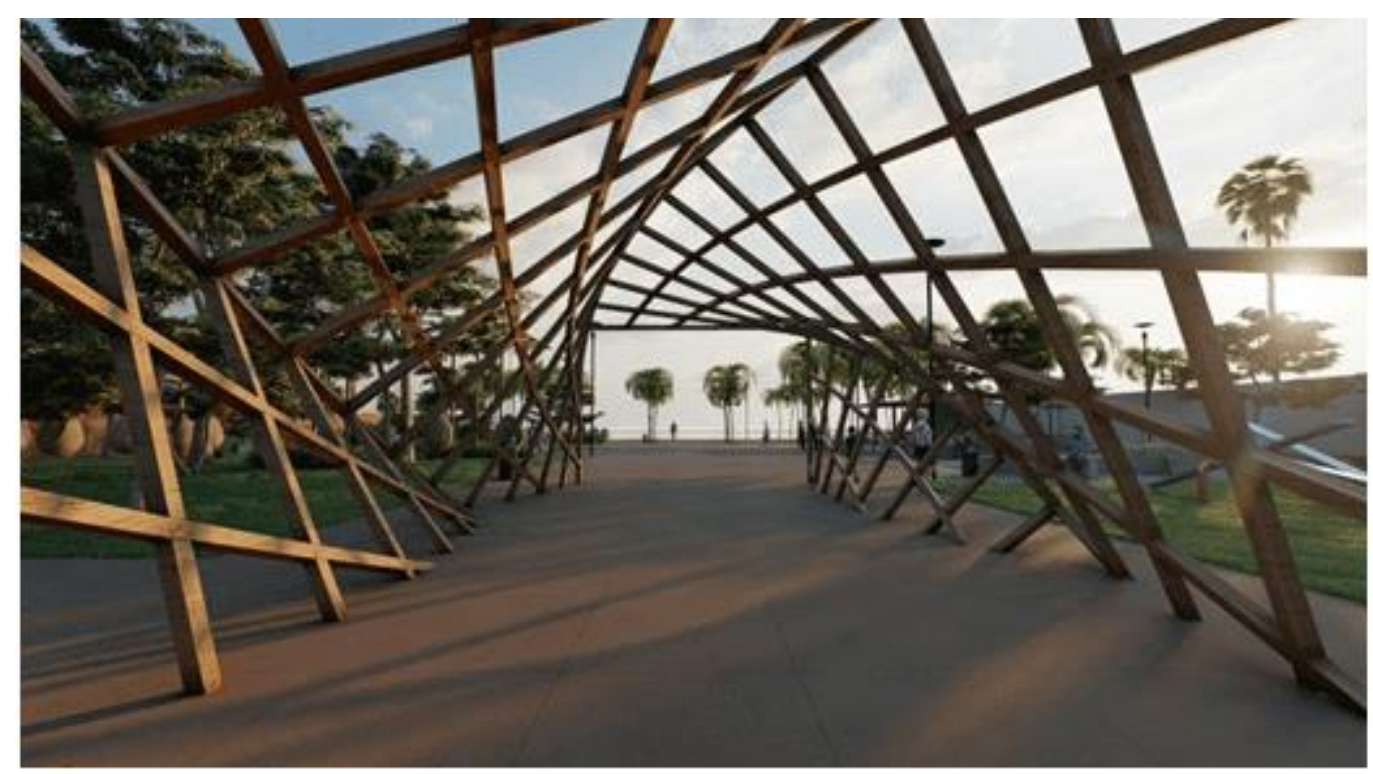

Fonte - Produzido pela autora

RC: 107028

Disponível em: https://www.nucleodoconhecimento.com.br/arquitetura/centro-deconvivencia 
Figura 28 - Perspectiva guarita

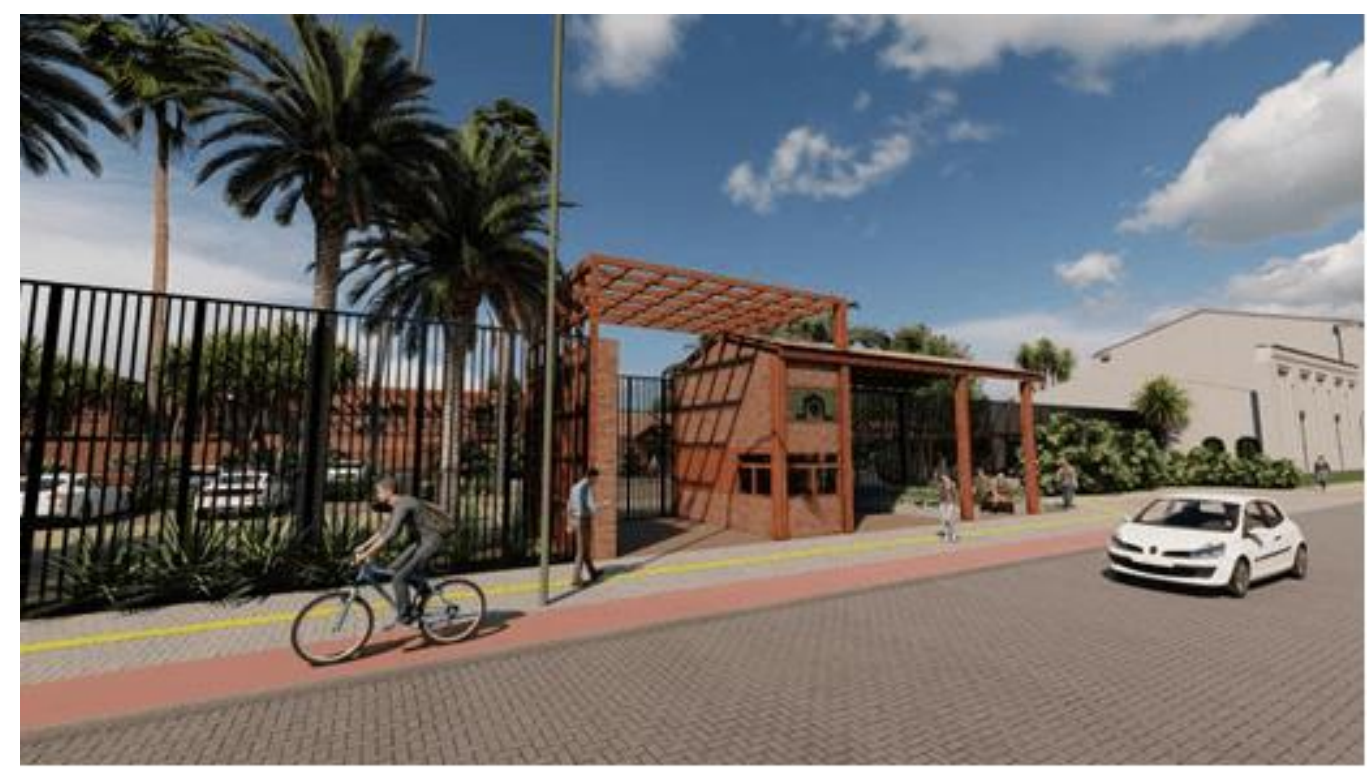

Fonte - Produzido pela autora.

Em suma, percebe-se que o projeto tem um olhar abrangente sobre as questões do envelhecimento, buscando prestar cuidados integrados, promover o envelhecimento ativo e atender às complexidades inerentes à idade e às transformações da sociedade.

\section{CONSIDERAÇÕES FINAIS}

Por fim, é perceptível que os estudos bibliográficos permitiram um maior entendimento das necessidades dos idosos. Assim, foram criados espaços adaptados a essas exigências que buscam permitir interações intergeracionais e promover a ocupação desse espaço público por todos. Nessa perspectiva, o atual depósito de contêineres será, então, reestruturado e transformado em um espaço público pertinente e completo para todas as gerações.

Buscando dar uma resposta à pergunta de partida (Como a arquitetura de um Centro de Convivência e Residência para a terceira idade pode contribuir para aumentar a autonomia dessa crescente população?) é possível afirmar que a solução está na

RC: 107028

Disponível em: https://www.nucleodoconhecimento.com.br/arquitetura/centro-deconvivencia 
promoção do bem-estar, envolvendo o pensamento crítico em relação a todas as limitações que o envelhecimento pode oferecer, buscando superá-las a partir das estratégias e elementos arquitetônicos aqui citados, o que promoverá o conforto em todas as suas esferas. Assim, por meio da acessibilidade, do projeto de assistência à saúde e ao desenvolvimento cognitivo e físico, se constrói a autonomia do idoso, dando-Ihe liberdade para exercer suas atividades diárias, promovendo, assim, um envelhecimento ativo, de modo que ele se sinta mais feliz, independente e funcional.

No mais, é notável uma expectativa para que os objetivos aqui propostos se concretizem a partir da arquitetura. Este projeto visa ser um ambiente motivador para a indução da autonomia do idoso e da sua integração com as outras gerações, envolvendo ações no campo da assistência social. Mas, para que a consumação da socialização do idoso, por meio de interações intergeracionais, de fato ocorra, é necessário somar esforços com a esfera pública, diante dos problemas sociais aqui apresentados, buscando alinhar-se com as Declarações dos Direitos Humanos e os direitos fundamentais do idoso, segundo a Constituição. Assim, deve haver um esforço do poder público para a promoção de projetos como este que visam atender à coletividade, incorporando valores de respeito ao idoso, vontade de socializá-lo e fazê-lo presente no dia a dia da população.

Ademais, como um edifício público, entende-se que sua projeção envolve outras questões além da vontade de transformar a sociedade. Envolve os cofres públicos, a disponibilidade de verbas para sua implantação e manutenção.

Em relação à manutenção, a sustentabilidade proposta ao Centro, por meio das estratégias passivas implementadas no projeto, visa gerar um baixo custo e baixo consumo de energia, de modo a tornar o projeto não somente ecologicamente correto ou socialmente justo, mas também economicamente viável a sua operação. Além disso, é possível utilizar alguns ambientes do Centro como locais que podem ser alugados, gerando renda própria.

RC: 107028

Disponível em: https://www.nucleodoconhecimento.com.br/arquitetura/centro-deconvivencia 
No que concerne à sua implantação, deve ser pensada como um investimento a longo prazo, que acompanha o crescente aumento da longevidade humana e da população idosa. Nesse sentido, a Organização Mundial de Saúde (2015) afirma que essas ações de saúde pública abrangente, relacionadas ao envelhecimento, inevitavelmente exigirão recursos, mas que se constituem um investimento sólido para o futuro da sociedade.

\section{REFERÊNCIAS}

ARAUJO, Claudia Lysia de Oliveira; SOUZA, Luciana Aparecida de; FARO, Ana Cristina Mancussi e. Trajetória das instituições de longa permanência para idosos no Brasil. HERE - História da Enfermagem Revista Eletrônica, Brasília, v. 1, n. 2, p. 250-262, 2010.

ASSOCIAÇÃO BRASILEIRA DE NORMAS TÉCNICAS. NBR 10151: acústica Avaliação do ruído em áreas habitadas, visando o conforto da comunidade Procedimento. Rio de Janeiro, 2000, 4 p.

NBR 15220: desempenho térmico de edificações. Parte 3: Zoneamento bioclimático brasileiro e diretrizes construtivas para habitações unifamiliares de interesse social. Rio de Janeiro, 2003, 23 p.

. NBR 15575: edificações habitacionais - Desempenho Parte 1: Requisitos gerais. Rio de Janeiro, 2013, 83 p.

NBR 9050: acessibilidade a edificações, mobiliário, espaços e equipamentos urbanos. Rio de Janeiro: 2020, 161 p.

BARBOSA, Ana Lúcia de Góes Monteiro. Conforto e Qualidade Ambiental no Habitat do Idoso. Rio de Janeiro: UFRJ/ FAU, 2001.

BATISTA, Analía Soria; JACCOUD, Luciana de Barros; AQUINO, Luseni; EL-MOOR, Patrícia Dario. Envelhecimento e dependência: desafios para a organização da

Disponível em: https://www.nucleodoconhecimento.com.br/arquitetura/centro-deconvivencia 
proteção social. Brasília: MPS, SPPS, 2008. 160 p. (Coleção Previdência Social; v. 28). Disponível em: (http://sa.previdencia.gov.br/site/arquivos/office/3_081208173354-810.pdf). Acesso em: 31/01/2022.

BRASIL. Decreto-lei ํㅡㄴ 25, de 30 de novembro de 1937. Presidência da República, Casa Civil. Organiza a proteção do patrimônio histórico e artístico nacional. Rio de Janeiro, RJ, 1937.

. Decreto-lei o 3.365, de 21 de junho de 1941. Presidência da República, Casa Civil. Dispõe sobre desapropriações por utilidade pública. Rio de janeiro, RJ, 1941.

. Portaria $n^{\circ} 810$, de 22 de setembro de 1989. Aprova normas e os padrões para o funcionamento de casas de repouso, clínicas geriátricas e outras instituições destinadas ao atendimento de idosos, a serem observados em todo - território nacional. Disponível em: (https://bvsms.saude.gov.br/bvs/saudelegis/gm/1989/prt0810_22_09_1989.html). Ac esso em: 31/01/2022.

BRASIL. Portaria SEAS № 73, de 10 de maio de 2001. Dispõe sobre Normas de funcionamento de serviços de atenção ao idoso no Brasil. Brasília, DF, 2001.

BRASIL. Lei Federal o 10.741, de 01 de outubro de 2003. Dispõe sobre o Estatuto do Idoso. Brasília, DF: 2003.2 Disponível em: (http://www.planalto.gov.br/ccivil_03/leis/2003/L10.741.htm). Acesso em: 28/02/2022.

BRASIL. Portaria no 2.528, de 19 de outubro de 2006. Dispõe sobre Política Nacional de Saúde da Pessoa Idosa, Brasília, DF, 2006. Disponível em: https://bvsms.saude.gov.br/bvs/saudelegis/gm/2006/prt2528_19_10_2006.html Acesso em: 31/01/2022. 
- Ministério da Saúde. Secretaria-Executiva. Departamento de Economia da Saúde e Desenvolvimento. Programação Arquitetônica de Unidades Funcionais de Saúde. Brasília: Ministério da Saúde, 2011.

\section{INSTITUTO BRASILEIRO DE GEOGRAFIA E ESTATÍSTICA} (IBGE). Censo Brasileiro de 2010. Rio de Janeiro: IBGE, 2012.

$$
\text { - INSTITUTO BRASILEIRO DE GEOGRAFIA E ESTATístICA (IBGE). }
$$

Pesquisa Nacional por Amostra de Domicílios Contínua. Rio de Janeiro: IBGE, 2016.

INSTITUTO BRASILEIRO DE GEOGRAFIA E ESTATÍSTICA (IBGE). Pesquisa Nacional por Amostra de Domicílios Contínua. Rio de Janeiro: IBGE, 2017.

Conselho Internacional de Monumentos e Sítios (ICOMOS). Carta de Veneza. Veneza, $\quad$ IT: $1964 . \quad$ Disponível em: (http://www.patrimoniocultural.gov.pt/media/uploads/cc/CartadeVeneza.pdf). Acesso em: 31/02/2022.

FROTA, Anésia Barros; SCHIFFER, Sueli Ramos; Manual de Conforto Térmico. São Paulo: Studio Nobel, 2001, 5. ed.

HALLACK, Mariana N. O. Centro de Convivência do idoso: arquitetura para a terceira idade. Juiz de Fora: Universidade Federal de Juiz de Fora, 2018.

LAMBERTS, Roberto; DUTRA, Luciano; PEREIRA, Fernando O. Rutkay. Eficiência Energética na Arquitetura. Rio de Janeiro: Eletrobrás/Procel, 2014, 3.ed.

LUTHER, Aline de Carvalho. A Companhia Empório Industrial do Norte e os vestígios da industrialização na Península de Itapagipe. In: $3^{\circ}$ SIMPÓSIO CIENTíFICO DO ICOMOS, 2019. Salvador, BA: UFBA, 2019, 3ํㅜ Brasil Belo Horizonte/MG, Universidade Federal da Bahia, Faculdade de Arquitetura.

Disponível em: https://www.nucleodoconhecimento.com.br/arquitetura/centro-deconvivencia 
ORGANIZAÇÃO DAS NAÇÕES UNIDAS. Departamento de Assuntos Econômicos e Sociais, Divisão de População (2019). World Population Prospects 2019: Highlights. Nova York: 2019.

ORGANIZAÇÃO MUNDIAL DA SAÚDE (OMS). Envelhecimento ativo: uma política de saúde. Brasília: Organização Pan-Americana da Saúde, 2005, Tradução Suzana Gontijo.

. Relatório Mundial de Envelhecimento e Saúde. Genebra: 2015, Sumário Executivo.

RIO DE JANEIRO. Centro de Apoio Operacional das Promotorias de Justiça de Proteção ao Idoso e à Pessoa com Deficiência. Boletim Informativo, n.47. Rio de Janeiro: MPRJ, 2016, p. 17, n.47.

SALVADOR. Lei ㄲo 9148/2016. Dispõe sobre o Ordenamento do Uso e da Ocupação do Solo do Município de Salvador. Salvador, 2016

SALVADOR. Secretaria Municipal da Saúde do Salvador (SMS SSA). Diretoria Estratégica de Planejamento e Gestão (DEPG). Plano Municipal de Saúde do Salvador 2018-2021. Salvador, 2018

SALVADOR. FGM - Fundação Gregório de Mattos. Salvador cultura todo dia. Disponível em: (http://www.culturatododia.salvador.ba.gov.br/vivendopolo.php?cod_area=3\&cod_polo=26). Acesso em: 10/03/2020.

SANTOS, Elisabete; PINHO, José A. G; MORAES, Luiz R. S; FISCHER, Tânia. 0 Caminho das Águas em Salvador: bacias Hidrográficas, Bairros e Fontes. Salvador: CIAGS/UFBA, SEMA, 2010.

Enviado: Janeiro, 2022.

Aprovado: Fevereiro, 2022. 